2006s-18

\title{
Regulation, Market Structure and Service Trade Liberalization
}

\author{
Denise Eby Konan, Ari Van Assche
}

\begin{tabular}{c}
\hline Série Scientifique \\
Scientific Series
\end{tabular}

Montréal

Septembre 2006

(C) 2006 Denise Eby Konan, Ari Van Assche. Tous droits réservés. All rights reserved. Reproduction partielle permise avec citation du document source, incluant la notice (C).

Short sections may be quoted without explicit permission, if full credit, including (C) notice, is given to the source.

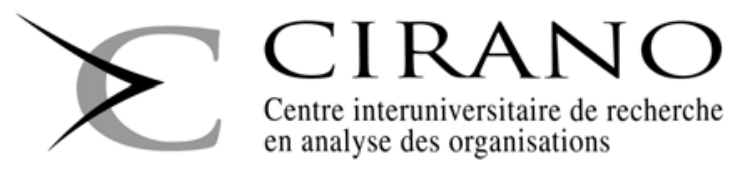




\section{CIRANO}

Le CIRANO est un organisme sans but lucratif constitué en vertu de la Loi des compagnies du Québec. Le financement de son infrastructure et de ses activités de recherche provient des cotisations de ses organisations-membres, d'une subvention d’infrastructure du Ministère du Développement économique et régional et de la Recherche, de même que des subventions et mandats obtenus par ses équipes de recherche.

CIRANO is a private non-profit organization incorporated under the Québec Companies Act. Its infrastructure and research activities are funded through fees paid by member organizations, an infrastructure grant from the Ministère du Développement économique et régional et de la Recherche, and grants and research mandates obtained by its research teams.

\section{Les partenaires / The Partners}

\section{Partenaire majeur}

Ministère du Développement économique, de l'Innovation et de l'Exportation

\section{Entreprises partenaires}

Alcan inc.

Banque du Canada

Banque Laurentienne du Canada

Banque Nationale du Canada

Banque Royale du Canada

Bell Canada

BMO Groupe financier

Bombardier

Bourse de Montréal

Caisse de dépôt et placement du Québec

Fédération des caisses Desjardins du Québec

Gaz Métro

Hydro-Québec

Pratt \& Whitney Canada

Raymond Chabot Grant Thornton

Autres partenaires gouvernementaux

Industrie Canada

Ministère des Finances du Québec

Ville de Montréal

\section{Partenaires universitaires}

École Polytechnique de Montréal

HEC Montréal

McGill University

Université Concordia

Université de Montréal

Université de Sherbrooke

Université du Québec

Université du Québec à Montréal

Université Laval

Le CIRANO collabore avec de nombreux centres et chaires de recherche universitaires dont on peut consulter la liste sur son site web.

Les cahiers de la série scientifique (CS) visent à rendre accessibles des résultats de recherche effectuée au CIRANO afin de susciter échanges et commentaires. Ces cahiers sont écrits dans le style des publications scientifiques. Les idées et les opinions émises sont sous l'unique responsabilité des auteurs et ne représentent pas nécessairement les positions du CIRANO ou de ses partenaires.

This paper presents research carried out at CIRANO and aims at encouraging discussion and comment. The observations and viewpoints expressed are the sole responsibility of the authors. They do not necessarily represent positions of CIRANO or its partners. 


\title{
Regulation, Market Structure and Service Trade Liberalization
}

\author{
Denise Eby Konan ${ }^{*}$, Ari Van Assche ${ }^{\dagger}$
}

\begin{abstract}
Résumé / Abstract
Dans ce papier, nous développons une méthode permettant de quantifier l'importance de la réglementation et de la structure des marchés sur la libéralisation du commerce et sur son succès. À ces fins, nous incorporons un secteur unique et imparfaitement compétitif pouvant intégrer différentes structures de marché dans un modèle standard de calcul d'équilibre général. Nous appliquons notre cadre d'analyse afin d'étudier l'impact de l'entrée d'un seul fournisseur étranger en Tunisie. Nous trouvons que si la réglementation du marché y garantit la compétition, le bien-être de la Tunisie peut augmenter de 0,65\%. Cependant, s’il y a formation d'un cartel entre le réseau domestique et l'entrant étranger, le bien-être de la Tunisie peut baisser de 0,25 \%. Nos résultats démontrent que tout en libéralisant son secteur des télécommunications, la Tunisie bénéficierait de réformes visant des régulations procompétitives.
\end{abstract}

Mots clés : CGE (équilibre général calculable), compétition imparfaite, libéralisation du commerce, réglementation, structure de marché

In this paper, we develop a method to quantify the importance of regulation and market structure on the success of trade liberalization. For this purpose, we incorporate a single imperfectly competitive service sector that can take on various market structures into a standard computational general equilibrium model. We apply our framework to analyze the impact of allowing a single foreign telecom provider to enter Tunisia. If the regulation environment guarantees competition, Tunisia's welfare can improve up to 0.65 percent. If a cartel is formed between the domestic incumbent and foreign entrant, however, Tunisia's welfare can drop up to 0.25 percent. Our results thus call for Tunisia among other developing countries to step up its procompetitive regulatory reforms while liberalizing its telecom sector.

Keywords: service trade liberalization, regulation, market structure, imperfect competition, CGE (Computable General Equilibrium)

Codes JEL : F12, F13, F23

\footnotetext{
${ }^{*}$ University of Hawaii at Manoa.

${ }^{\dagger}$ Correspondence: HEC Montréal, Department of International Business, 3000 Chemin de la Côte-Sainte-

Catherine, Montréal (Québec), Canada H3T-2A7. E-mail: ari.vanassche@hec.ca.
} 


\section{Introduction}

Within a long tradition of multilateral trade policy, negotiations on services trade is the 'new kid on the block.' First introduced about 25 years ago at the 1982 GATT Ministerial Meeting, the services policy agenda remains a sideline to more traditional cross-border trade negotiations. This is surprising as globalization relies on the availability of quality services such as telecommunications, transportation, insurance, and financial services. A substantial multilateral agreement to liberalize trade in services would have an impact far beyond that achievable through the further reduction of trade barriers goods such agriculture, electronics, or textiles. Yet, the potential gain from trade liberalization in services is not well understood.

While the importance of services is increasingly recognized by international trade economists, empirical studies remain in scant supply for a number of reasons (Hoekman 2006). ${ }^{1}$ For one, it is difficult to measure the international flow of services provision as multiple modes of delivery are involved. For example, certain services (local telecommunications) can only be provided through the establishment of a domestic presence. Yet, national income accounts do not systematically include data on employment, output, or sales of foreign subsidiaries. Second, international activities in key services industries are subject to restrictions on market entry, foreign ownership, and other regulatory barriers. Quantifying the impact of these barriers is more difficult than would be implied by an estimation of a tariff or other ad valorem equivalent. Third, high fixed costs and legal barriers to entry in services sectors combine to make markets imperfectly competitive. Liberalizing services in these imperfectly competitive markets may be akin to inviting a foreign firm to join a cartel (Francois and Wooton 2001). Foreign firms may share in the collection of real economic rents, and may shift these rents abroad. The outcome of liberalization depends not only on pre-reform conditions but also on the selection of new entrants and the competitive behavior of the foreign licensees upon entry into the market.

In this paper, we develop a theoretical method to model the joint effect of regulation and market structure on services liberalization within a general equilibrium context. The model is applied to the liberalization of telecommunications within a computable general equilibrium model of Tunisia.

Existing CGE studies on service trade liberalization have largely neglected the role of market structure on the success of service trade liberalization due to theoretical complications related to introducing imperfect

\footnotetext{
${ }^{1}$ A notable exception is Arnold, Javorcik and Mattoo (2006).
} 
competition into a CGE framework. To model service trade liberalization, studies have generally incorporated tariff equivalents of impediments to service trade into standard CGE trade models. ${ }^{2}$ Brown, et al. (1996), for example, convert Hoekman (1995)'s frequency indices into an ad-valorem tariff equivalent and use this approach to simulate service trade liberalization in their multi-country Michigan Model of World Production and Trade. Hertel (1999) approximates cross-border barriers with Francois and Hoekman's (1999) gravity-equation estimates and simulates service trade liberalization in the multi-country GTAP model. Dee and Hanslow (2001), Brown and Stern (2001) and Jensen, Rutherford and Tarr (2004) take similar approaches in CGE models with endogenous FDI flows.

This approach does not allow one to analyze the role of strategic behavior and market structure on the success of service trade liberalization (Whalley, 2004). In the CGE models discussed above, it is assumed that the service sectors are governed by perfect competition or large-group Dixit-Stiglitz monopolistic competition both before and after service trade liberalization. Service trade liberalization is modeled as the removal of the ad valorem tariff equivalents of the impediments of services trade. This approach is inappropriate to analyze the effects of trade liberalization in service sectors where domestic regulation limits market entry to both domestic and foreign providers for two reasons. First, especially in developing countries many backbone services sectors such as telecommunications, finance and insurance are governed by few large players. Second, recent service liberalization discussions have focused primarily on freeing up ownership restrictions rather than necessarily allowing free entry per se (Low and Mattoo, 2000). If service liberalization only leads to partial market entry without pro-competitive regulatory reforms, then this entails a danger that the foreign firms form a cartel with domestic firms. In that case, monopoly markups do not disappear, while rents might be transferred abroad (Low and Mattoo, 2000; Copeland, 2002). In a recent World Bank study, Mattoo and Sauvé (2003) have thus concluded that the success of service trade liberalization is strongly related to issues of market structure and domestic regulation.

\footnotetext{
${ }^{2}$ Hoekman (1995) developed a frequency indicator as an initial attempt to quantify the presence of barriers based on the GATS schedule of commitments by country. While this provides some indication of the extent of commitments, the index is not designed to measure the level of barriers present. Francois and Hoekman (1999) derive a quantitybased measure by fitting a gravity model of bilateral services trade between the U.S. and its trading partners. Discrepancies in predicted trade patterns are used to indicate the severity of service trade barriers. Findlay and Warren (2000), finally, describe an ongoing Australian services research project to create price-based measures of service trade barriers by determining the wedge between price and marginal cost in service sectors.
} 
In a recent study, Konan and Maskus (2006) have conducted a first attempt to quantify the role of market structure on the success of service trade liberalization in Tunisia. The authors take the simplifying assumption that service sectors are governed by perfect competition, but they identify that service trade barriers lead to two types of markups above world-best marginal cost: an inefficiency markup since more efficient foreign firms are kept out of the domestic market, and a cartel markup because the trade barriers reduce competition in the market. By comparing the welfare effects of service trade liberalization when the cartel markup disappears or remains, they are able to provide initial quantitative insights into the role of market structure on the success of service trade liberalization.

The problem of introducing imperfectly competitive market structures other than Dixit-Stiglitz monopolistic competition into CGE models is largely theoretical. CGE models are based on input-output tables where industries with different elasticities of demand buy the same goods and services. To derive an imperfectly competitive firm's Lerner markup condition in such models, one is required to calculate the general equilibrium demand elasticities for all users and weight them appropriately. A recent contribution from Hoffmann (2002) demonstrates the complexities that are involved with calculating such Lerner markup rules under Cournot competition. He shows that a firm uses a weighted average of the different buyers' general equilibrium elasticities of demand to maximize profits, where the weights equal the share sold to each buyer.

This paper contributes to the existing literature by analyzing the role of market structure in the liberalization of one single service sector. For this purpose, we extend Hoffmann's (2002) method by incorporating a single imperfectly competitive services sector into a standard CGE framework and deriving the Lerner markup conditions for multiple market structures: monopoly, oligopoly, cartel and monopolistic competition. This extension allows us to analyze the role of market structure on the effect of partial service trade liberalization in a single sector. Assume that in the benchmark scenario only one or few domestic service providers operate in a services sector. In the counterfactuals, the services sector is liberalized and one or more licenses are provided to foreign service providers. If regulations can enforce competition between the domestic and foreign providers, then the telecommunications market structure turns into a Cournot oligopoly. If regulations are weak, then the domestic and foreign providers form a cartel. We discuss the welfare effects associated with the adoption of different market structures in such a framework.

In the second part of our paper, we introduce our method into a CGE 
model for Tunisia to investigate the possible welfare impacts of allowing one foreign provider to enter Tunisia's telecommunications sector. Our results highlight the role that market structure plays in Tunisia's telecommunications liberalization. According to our conservative estimates, the potential welfare implications of telecom liberalization are clearly positive if competition can be guaranteed between the two providers. Tunisia's welfare is estimated to increase up to 0.65 percent if the foreign provider is more efficient and does not shift its profits abroad. In contrast, telecom liberalization can lead to a welfare deterioration of up to 0.25 percent if the two providers collude and the foreign provider shifts its profits abroad. Our results thus call for Tunisia to step up its pro-competitive regulatory reforms while liberalizing its telecom sector.

The paper is organized as follows. In Section 2, we introduce an imperfectly competitive service sector that can adopt various market structures into a standard CGE framework. In Section 3, we define the various welfare effects that can be associated with service trade liberalization. In Section 4, we apply our framework to telecommunications liberalization in Tunisia. Section 5 concludes.

\section{$2 \quad$ Model}

Consider a CGE model with $I-1$ perfectly competitive sectors that produce output $Y_{i}$ and one imperfectly competitive producer service sector that provides service $Y_{z}$. Sectoral output is used both as an intermediate good by sectors $I$ and as a final good by the representative consumer. We denote intermediate good use by superscript $x$ and final good use by superscript $c$. In the imperfectly competitive producer service sector $Y_{z}, N$ service providers each produce a single differentiated service $z_{j}$. The service providers are not necessarily symmetric and can be both domestic and foreign. Users perceive a constant elasticity of substitution between each provider's service, and we thus represent total industry output $Y_{z}$ as a CES function of services provided by each provider $z_{j}$ :

$$
Y_{z}=\left(\sum_{j=1}^{N} z_{j}^{\epsilon}\right)^{\frac{1}{\epsilon}}
$$

The elasticity of substitution between each variety is $\sigma=\frac{1}{1-\epsilon}$, where $\sigma>1$.

Producer service sector $Y_{z}$ is one of a select group of $H$ producer services that positively affect value-added productivity when used as an intermediate 
good (Markusen, Rutherford and Tarr, 2000; Markusen, Rutherford and Tarr, 2005). Telecommunications, finance, insurance, business services and transportation are generally considered to belong to this category. To model this, we assume that industry $i \in I$ 's composite producer services $P S_{i}$ is a Leontief function of the share of producer service sector $H$ 's output allocated to sector $i$ :

$$
P S_{i}=\min \left[\frac{Y_{1, i}^{x}}{\kappa_{1, i}}, \ldots, \frac{Y_{H-1, i}^{x}}{\kappa_{H-1, i}}, \frac{Y_{z, i}^{x}}{\kappa_{z, i}}\right] .
$$

Composite producer services $P S_{i}$ are an imperfect substitute to value added $K_{i}^{\alpha_{i}} L_{i}^{\beta_{i}}$ in that industry:

$$
V_{i}=\left[\left(K_{i}^{\alpha_{i}} L_{i}^{\beta_{i}}\right)^{\gamma}+P S_{i}^{\gamma}\right]^{\frac{1}{\gamma}}
$$

where the constant elasticity of substitution between value added and producer services is $\rho=\frac{1}{1-\gamma}$. We call function $V_{i}$ composite value added of industry $i$. The production function for all sectors except for $Y_{z}$ is approximated with Leontief technologies using composite intermediate inputs from $i \notin H$ and composite value added $V$ allocated to the industry.

$$
Y_{i}=\min \left[\frac{Y_{H+1, i}^{x}}{\lambda_{H+1, i}}, \ldots, \frac{Y_{I, i}^{x}}{\lambda_{I, i}}, \frac{V_{i}}{\lambda_{v, i}}\right] .
$$

Similarly, The Leontief production function for firm $j$ in sector $Z$ takes the following form:

$$
z_{j}=\min \left[\frac{Y_{H+1, j}^{x}}{\lambda_{H+1, j}}, \ldots, \frac{Y_{I, j}^{x}}{\lambda_{I, j}}, \frac{V_{j}}{\lambda_{v, j}}\right] .
$$

Finally, preferences of the representative consumer are represented by a Cobb-Douglas utility function.

$$
U(C)=\prod_{i=1}^{I} Y_{i, c}^{\mu_{i}} .
$$

\subsection{Market Structure and Lerner Markup Conditions}

Firms in the imperfectly competitive services sector $Y_{z}$ do not price discriminate, but sell their services to all sectors in the economy and to the representative agent at the same price. Since each user might have a different demand elasticity for the service, a question arises which markup rule the service provider will choose to maximize profits. Hoffmann (2002) illustrates that the general equilibrium Lerner markup condition for a service provider 
$j$ in that case is a weighted average of the perceived demand elasticities for the different users: ${ }^{3}$

$$
p_{j}^{k}=\left(1+\frac{1}{\omega_{u} \Phi_{j, u}^{k}+\sum_{i} \omega_{i} \Phi_{j, i}^{k}}\right) c_{j}(w, r),
$$

where $\omega_{u}$ and $\omega_{i}$ stand for the share of services $Z$ that are sold to the representative consumer and sector $i$ respectively. $\Phi_{j, u}^{k}$ and $\Phi_{j, i}^{k}$ represent provider $j$ 's perceived demand elasticity from the representative consumer and from sector $i$ in market structure $k$, respectively. Finally, $c_{j}(w, r)$ is service provider $j$ 's marginal cost of production, which depends on wages $w$ and the return to investment $r$.

To compute the general equilibrium markup condition for each firm $j$ under each market structure $k$, we will proceed by first deriving the perceived demand elasticity for intermediate inputs $\Phi_{j, i}^{k}$ and then calculating the perceived demand elasticity for final demand $\Phi_{j, u}^{k}$. Finally, we will insert all elasticities into equation (7) to derive the general equilibrium Lerner markup condition.

\subsubsection{Demand Elasticity for Intermediate Inputs}

To determine $\Phi_{j, i}^{k}$, we first need to derive the price $p_{j}^{k}$ that service provider $j$ charges under each market structure $k$. To simplify notation, we will drop superscript $k$ throughout the derivation of the general equilibrium Lerner markup condition. Let $P_{y}$ denote the domestic price of final good output $Y_{i}$ in sector $i$ and $p_{j}$ denote the price received by service provider $j$ in sector $Z$. Note that $P_{y}$ and $p_{j}$ do not differ from sector to sector since we assume that there is no price discrimination. Since final $Y_{i}$ production is assumed perfectly competitive in our model, $p_{j}$ is the value of the marginal product of $z_{j}$ in producing $Y_{i}$. The price of service $p_{j}$ can thus be derived from the chain rule:

$$
p_{j}=P_{y} \frac{\partial Y_{i}}{\partial Y_{z, i}^{x}} \frac{\partial Y_{z, i}^{x}}{\partial z_{j, i}} .
$$

We derive $p_{j}$ in Appendix $B$. Using the price function, we can then derive the inverse of the perceived elasticity of demand from sector $i$ for provider

\footnotetext{
${ }^{3}$ In appendix A, we replicate the derivation of Hoffmann's (2002) optimal markup condition.
} 
$j$ under each market structure $k$ :

$$
\frac{1}{\Phi_{j, i}}=\left\{\begin{array}{lll}
s_{v, i}(1-\gamma) & \text { if } & \text { monopoly } \\
s_{v, i}(1-\gamma) & \text { if } & \text { cartel } \\
1-\epsilon-s_{j}\left(\left(1-\epsilon-s_{v, i}(1-\gamma)\right)\right. & \text { if } & \text { oligopoly } \\
1-\epsilon & \text { if } & \text { monopolistic competition }
\end{array}\right.
$$

where $s_{v, i}=\frac{p_{v, i}^{1-\rho}}{p_{v, i}^{1-\rho}+p_{p s, i}^{1-\rho}}$ and the market share of provider $j$ equals $s_{j}=$ $\frac{p_{j}^{1-\sigma}}{\sum_{j=1}^{N} p_{j}^{1-\sigma}}$. A comparison across market structures identifies that service providers in a cartel each act as if they are a monopolist with a share $s_{j}=1$. In addition, the inverse of the perceived demand elasticity under a Cournot oligopoly reduces to the monopoly scenario when $s_{j}=1$ and to the monopolistic competition scenario when $s_{j}=0$. Taking into account these characteristics, we can generalize the inverse of the perceived demand elasticity to:

$$
\frac{1}{\Phi_{j, i}^{k}}=1-\epsilon-s_{j}^{k}\left(1-\epsilon-s_{v, i}(1-\gamma)\right)
$$

where $s_{j}^{k}$ is perceived to be equal to 1 under a cartel, and equals provider $j$ 's actual market share otherwise.

\subsubsection{Demand Elasticity for Final Demand}

We next derive provider $j$ 's perceived demand elasticity from the final consumer. Since preferences of the representative consumer are represented by a Cobb-Douglas utility function, the industry demand elasticity equals to one. As a result, the perceived demand elasticity for each provider equals to 1 under a monopoly and a cartel. It is straightforward to demonstrate that under an oligopoly, the perceived final demand elasticity for provider $j$ is:

$$
\frac{1}{\Phi_{j, u}^{k}}=1-\epsilon\left(1-s_{j}^{k}\right)
$$

where $s_{j}^{k}$ is perceived to be equal to one under a cartel, and equals provider $j$ 's actual market share otherwise. ${ }^{4}$

\footnotetext{
${ }^{4}$ See Head and Mayer (1999) for proof.
} 


\subsubsection{General Equilibrium Lerner Markup Condition}

We can now insert equations (9) and (10) into equation (7) to find the general equilibrium Lerner markup condition for each provider $j$ under each market structure $k$ :

$$
p_{j}^{k}=\frac{\Sigma_{j}^{k}}{\sum_{j}^{k}-1} c_{j}(w, r),
$$

where

$$
\Sigma_{j}^{k}=\left(\frac{\omega_{u}}{1-\epsilon\left(1-s_{j}^{k}\right)}+\sum_{i} \frac{\omega_{y, i}}{\left(1-s_{j}^{k}\right)(1-\epsilon)+s_{v, i} s_{j}^{k}(1-\gamma)}\right) .
$$

From equations (11) and (12), the general equilibrium markup above marginal cost $\frac{\Sigma_{j}^{k}}{\Sigma_{j}^{k}-1}$ reduces to $\frac{\sigma}{\sigma-1}$ if $s_{j}^{k}=0$. The markup rises in $s_{j}^{k}$ as long as the realistic condition $s_{v, i}(1-\gamma)+\epsilon \geq 1$ holds.

The price of the composite service $P_{z}$ then becomes:

$$
P_{z}^{k}=\left(\sum_{j} p_{j}^{k^{1-\sigma}}\right)^{\frac{1}{1-\sigma}}=\left(\sum_{j}\left(\frac{\sum_{j}^{k}}{\sum_{j}^{k}-1} c_{j}(w, r)\right)^{1-\sigma}\right)^{\frac{1}{1-\sigma}},
$$

\subsection{Service Trade Liberalization}

This model setup can be used to analyze the welfare effects of service trade liberalization in a country that in the benchmark is dominated by a small number of domestic firms in a single producer services sector $Y_{z}$. In the counterfactual scenarios, the effect of service trade liberalization can then be quantified by allowing one or more foreign providers to enter the market. If a pro-competitive regulatory environment is in place, the domestic incumbent and foreign market entrant(s) strategically compete in quantities. Otherwise, competition is not ensured and the domestic incumbent and foreign entrant(s) form a cartel. As such, this setup allows us to analyze the impact of regulation and market structure on the success of service liberalization in the imperfectly competitive sector.

To structure our welfare analysis, we assume that providers from the same country are identical. Foreign providers, however, may differ from the domestic incumbents in two respects. First, foreign providers may shift a portion of their profits abroad, while the domestic incumbent shifts all of its profits to the domestic representative agent. Second, foreign providers may be more efficient in the sense that they face a lower marginal cost $c_{j}(w, r)$. 
Let $c^{*}$ denote the best-practice marginal cost and $\Delta_{j}$ the resource-using service barrier:

$$
p_{j}^{k}=\frac{\Sigma_{j}^{k}}{\sum_{j}^{k}-1}\left(1+\Delta_{j}\right) c^{*}(w, r),
$$

where $\Delta_{d} \geq \Delta_{f} \geq 0$. Similar to Konan and Maskus (2006), this implies that the total price-cost wedge can be decomposed into two types of wedges. On the one hand, barriers to FDI and excessive regulation create a cartel wedge $\frac{\Sigma_{j}^{k}}{\Sigma_{j}^{k}-1}$ by limiting both domestic and foreign participants in certain service sectors and thus hampering competition. On the other hand, the exclusion of low-cost foreign suppliers from the market and the additional costs of bureaucratic procedures create a cost inefficiency wedge $1+\Delta_{j}$. As we shall see below, the size of the wedges play an important role on the welfare impact of service trade liberalization.

The differences between domestic and foreign providers introduce a realistic trade-off related to service trade liberalization: on the one hand, service trade liberalization can be welfare improving since it provides users with more variety (love-of-variety effect), can induce more competition in the sector (pro-competitive effect), and can allow more efficient foreign firms to operate in the market (efficiency effect). On the other hand, it can be welfare reducing since the foreign providers may shift a portion of their profits abroad. We will now analyze the four welfare effects separately.

Users of producer service $Y_{z}$ treat each new variety as an imperfect substitute from that of the domestic incumbent. This implies that service trade liberalization leads to a positive love-of-variety effect through a reduction in the price of composite service $P_{z}$. To demonstrate this, suppose that service trade liberalization induces $n-1$ foreign providers to enter the market and form a cartel with the domestic incumbent. Assume that they are equally efficient as the domestic incumbent and that they shift all of their profits to the domestic representative agent. From equation (11), the $n-1$ foreign providers will set their price equal to the domestic incumbent's pre-liberalization price. From equation (13), this implies that the price of composite services $P_{z}$ is lower than in the initial domestic monopoly:

$$
n^{\frac{-1}{\sigma-1}} p_{j} \leq p_{j}
$$

Service trade liberalization thus leads to a positive love-of-variety effect.

A second positive welfare effect that can be induced by service trade liberalization is a pro-competitive effect. To demonstrate this, suppose that the $n-1$ foreign providers that have entered the market compete in quantities 
instead of forming a cartel. In that case, each provider perceives to have a market share $s_{j}^{k}<1$. From equation (12), this implies that $\Sigma_{j}^{k}$ is larger than under a cartel. ${ }^{5}$ From equation (13), this implies that the composite service price $P_{z}$ is smaller under Cournot competition than under cartel. When competition is guaranteed, service trade liberalization thus leads to a positive pro-competitive effect.

A third positive welfare effect that may be associated with service trade liberalization is an efficiency effect. To demonstrate this, suppose that the $n-1$ foreign service providers' marginal cost of production is lower than the domestic incumbent's marginal cost of production: $c_{f}(w, r)<c_{d}(w, r)$. Since the market share of the foreign providers will be higher than the domestic incumbent, the foreign providers will partially offset the lower marginal cost by charging a higher markup (see equation (11))). Nonetheless, the general equilibrium price of the foreign providers is always lower than that of the domestic incumbent: $p_{f}<p_{d}$. From equation (13), the composite price $P_{z}$ then is lower than in the scenario where the foreign providers are as efficient as the domestic incumbent. Service trade liberalization in that case leads to a positive efficiency effect.

Finally, a negative welfare impact may be associated with service trade liberalization. If the foreign provider shifts its profits abroad rather than to the domestic representative agent, then this leads to a negative income effect for the representative consumer. In that case, service trade liberalization can lead to a negative profit-shifting effect.

There are other welfare effects associated with partial service trade liberalization that we do not take into account in this paper. For example, if the government competitively auctions off its licenses to foreign providers, then this can create a positive license fee effect. In this paper, we do not consider the auctioning off of licenses by taking on the implicit assumption that a government gives a license to a select (number of) foreign provider(s) for free.

The opposing welfare effects imply that in theory the welfare impact of service trade liberalization is ambiguous and depends on the parameters of the model. In the next section, we will apply our model to telecommunications liberalization in Tunisia to demonstrate the magnitudes of the various effects.

\footnotetext{
${ }^{5}$ This will be the case under the realistic condition that $s_{v, i}(1-\gamma)+\epsilon \geq 1$.
} 


\section{Telecommunications Liberalization in Tunisia}

Tunisia represents a good case study to investigate the impact of regulation and market structure on the success of telecommunications liberalization. Tunisia's telecommunications sector is one of the least advanced among developing countries in terms of market liberalization. The Tunisian telecommunications market has long been characterized by the monopoly of Tunisie Telecom and the extensive role of the government as policy-maker, regulator and operator in the sector. Tunisie Telecom, also known as "Office National des Télécommunications" continues to be a $100 \%$ state-owned company with a national monopoly on fixed telephony services and on the provision of internet infrastructure. Until recently, Tunisie Telecom also had a monopoly on the mobile telephony through its subsidiary Tunicell. Only in 2002 was the country's first private mobile telecommunications license sold to the Egyptian consortium Orascom. As is illustrated in figure 1, this makes Tunisia's telecommunications sector one of the least advanced among developing countries in terms of market liberalization. Tunisia's telecommunications liberalization index in 1999 was below the average of the worstperforming developing region in the world, that is, the MENA region. ${ }^{6}$ In addition, although Tunisia has initiated reforms in the past six years, its telecommunications liberalization index continues to fall far short of the average ratings achieved by developing countries with similar levels of GDP per capita (Varoudakis and Rossotto, 2004).

\section{[Figure 1 about here]}

Tunisia's lack of telecom liberalization has led to an underperforming telecom sector. As is depicted in Figure 2, Tunisia's fixed line penetration rate was similar to other Lower Middle-Income Countries between 1980 and the early 1990s. From 1994, however, Tunisia has lagged behind since. In addition, the mobile phone penetration rate in Tunisia has continuously remained below that of other Lower Middle-Income Countries. For these reasons, telecom liberalization holds a considerable potential for improving not only Tunisia's sectoral performance, but also its overall economic performance.

\footnotetext{
${ }^{6}$ The telecommunications liberalization index was constructed by Varoudakis and Rossotto (2004). It measures degrees of liberalization according to: (i) degree of effective competition; (ii) openness to FDI in telecommunications; and (iii) pro-competitive regulation and independence of regulatory body.
} 
[Figure 2 about here]

The Tunisian government has recognized this potential and has committed to a cautious program of telecommunications liberalization. In 1997, it was one of the 56 signees of the World Trade Organization Agreement of Basic Telecommunications Services, thus committing itself to gradually opening up its telecommunications sector to foreign competition. In accordance to the Agreement, Tunisia committed to permitting telex and data transmission competition from 1999, mobile telephone and paging, frame relay, and teleconferencing from 2000, and local telephone competition in $2003 .^{7}$ However, Tunisia was less inclined to make binding commitments to pro-competitive regulatory reforms. During the GATS Telecommunications negotiations, Tunisia was one of the few signees that refrained from signing on to the Reference Paper, which committed members to a schedule of pro-competitive regulatory reforms.

In January 2001, Tunisia enacted a new Communications Code (Law n. 2001-1), which would regulate the telecommunications sector. The law enabled the opening-up of the market to private companies by introducing a licensing regime for the supply of telecommunications services and networks. In addition, the Code created two regulatory agencies: the National Instance of Telecommunications (NIT) and the National Agency for Frequency (NAF). The NIT is in charge of the regulation of the telecommunications sector and the NAF is in charge of spectrum management. But, once again, the Code falls short of setting up an independent regulatory agency since significant lawful capacities are left to the Ministry of Communications Technologies with regard to licence awarding, dispute settlements and application of sanctions.

In summary, Tunisia's telecom sector is currently dominated by a large domestic player. The Tunisian government is aware of the potential benefits that telecom liberalization may enhold and is taking initial steps to liberalize the market. It is wary of committing to full-fledged liberalization, however, and has been reluctant to embrace significant regulatory reforms.

The model framework that we have developed in Section 2 is can provide a valuable quantitative analysis of the macro and sectoral implications of partial telecom liberalization in Tunisia. In addition, we are able to quantify the dangers associated with neglecting adequate regulatory reforms, thus

\footnotetext{
${ }^{7}$ For all services, foreign ownership was capped at $49 \%$, and foreign ownership of Tunisie Telecom was only permitted to $10 \%$ beginning in 2002 .
} 
helping to shape policy recommendations. In the next section, we discuss the data and model structure that we use to conduct our analysis.

\subsection{Model Structure and Benchmark Data}

To introduce Section 2's theoretical model into a CGE framework for Tunisia, we need to take on a number of behavioral assumptions concerning Tunisia's telecommunication sector. First, we assume that the telecom sector is the only imperfectly competitive sector in Tunisia and that it in the benchmark is governed by a domestic monopoly. Second, we assume that the telecom sector is one of five producer services sector next to finance, insurance, business services and transportation. Third, we use Konan and Maskus' (2006) estimate that the price-cost wedge in Tunisia's telecom sector is $30 \%$.

As is explained above, the price-cost wedge can be decomposed into two types of wedges: a cartel wedge and a cost inefficiency wedge. Since we do not have the empirical information to determine the relative size of these two wedges, we assume that in the benchmark both wedges are of equal weight. In other words, the domestic monopolist in the benchmark faces a marginal cost that is $15 \%$ above the world's best practice (cost inefficiency wedge) and a cartel wedge of $15 \%$.

The nesting structure of the Tunisia CGE model builds on the theoretical framework built in Section 2 and is depicted in Figure 3. The list of the main equations is provided in Appendix C. We assume that all sectors other than the telecom sector is characterized by constant returns to scale and perfect competition, implying that prices equal marginal cost of output. In all sectors, production functions are approximated with Leontief technologies using composite intermediate inputs and composite value added. Composite value added is approximated with a CET technology using producer services and real value added. A Cobb-Douglas production function describes the substitutability between labor and capital inputs in producing value added. Intermediate inputs and final goods are differentiated by country of origin according to the Armington assumption, so that export and import prices differ across regions. The three trading regions are the European Union (EU), the Arab League Countries (MENA) and the rest of the world (ROW).

\section{[Figure 3 about here]}

In each sector, demand for domestically produced and imported goods is represented by a CES function, and intermediate imports are also differentiated 
across regional sources of supply in a CES structure. Similarly, industries supply regionally differentiated goods to both domestic and foreign markets (exports). Production follows a nested two-stage constant elasticity of transformation (CET) function. Total output is first calculated as the sum of domestic supply and total exports, with the latter then being allocated across the same destination regions according to a sub-CET function. Capital and labor are assumed to be freely mobile across sectors, whereas the stock of factor endowments are endogenous, implying that our simulations pertain to long-run outcomes of telecom liberalization.

A representative consumer maximizes a nested CES utility function with a corresponding multi-staged budget constraint. In the first stage, the consumer decides how much to spend on goods from each sector, given the budget constraint. Income elasticities across sectors are set at unity as given by a Cobb-Douglas (CD) utility nest. In the second nest, the consumer determines domestic and aggregate import expenditures in each sector according to a CES function. Then given a budget for imports, the consumer selects purchases of imports from each region. These latter functions also characterize the split between government consumption and investment spending on domestic and imported goods and services. The representative consumer receives income from primary factors (labor and capital), net transfers from the government, the current-account deficit, and any net economic rents from the operation of restrictions on telecom trade.

Two standard closure rules are imposed: the savings-investment balance and a fixed current-account balance. The savings-investment balance is based on the assumption that the capital stock is exogenously fixed at the benchmark level. This stock is financed through forced consumer savings that act as a direct (lump-sum) tax. The interest rate (an index price of the composite capital stock) is endogenous and determined by factor-demand conditions. The current-account balance is the sum of the merchandise trade balance, the services balance, net foreign worker remittances, and (negative) net payments on foreign capital. We assume that foreign reserves will be held constant so that the current account will be just offset by (the negative of) the capital account. The current-account balance itself is held constant in real terms throughout the simulations. Income from foreign remittances less foreign capital payments enters as an exogenous addition to the representative agent's income. To hold the current-account balance fixed while international prices are constant requires a balancing item. This is accomplished by means of a change in the home "real exchange rate," which refers implicitly to a change in the home price index (generated by changes in price of home-produced goods) sufficient to sustain a constant 
current-account balance as import and export volumes change.

The government budget deficit is a deduction in available income for the representative agent, constituting a transfer to government consumption. The deficit is held fixed during our simulations. Thus, if a policy reform causes prices to fall, thereby reducing the tax revenues required to finance government expenditures, this tax saving is transferred to the representative agent. At the same time, if trade liberalization results in lost tariff revenues, the revenues are recouped by means of allowing household lump-sum taxes to vary endogenously.

The data required for the CGE model consist of a Social Accounting Matrix (SAM) and of other parameters such as import and export trade flows by region and elasticities of substitution and transformation. The core input-output model is the 1995 table provided on a diskette by the Institut National de la Statistique (INS). The 56 sector table was combined with the INS Les Comptes de la Nation (1998) report and then assembled into a consistent set of relationships between intermediate demand, final demand and value-added to produce the SAM. In Table 1, we use this dataset to present each industry's telecom usage intensity, producer service usage intensity and labor intensity. The industries are ranked in descending order by telecom usage intensity (column 2). The ten industries with the highest telecom input as share of sectoral output all are service sectors. Agriculture, automobile \& trucks and food are the three industries with the lowest telecom usage intensity.

\section{[Table 1 about here]}

Trade and tariff data were aggregated to the input-output sectoral basis using import weights consistent with the concordance between the inputoutput table and the tariff classification. Tariff rates were determined by collections data for 1995 and vary across regions due to duty drawback provisions as well as preferential treatment of the EU and the Arab League. There are no data on tariff collections on services, reflecting the absence of formal trade taxes, and we take their tariff rates to be zero. This treatment is the same as that in Chatti (2000), while Brown, Deardorff and Stern (1997) assume there are no barriers to trade in Tunisian services.

More information about the data can be found in Konan and Maskus (2006). In addition, we have made the data available for the GTAP model version 6 (Konan and Van Assche, 2005). 
Because there is little empirical evidence on relevant elasticities for the Tunisian market, we make standard assumptions about their values. In particular, labor-capital substitution is set at unity in a Cobb-Douglas valueadded production function. Benchmark trade elasticities are drawn from Rutherford, Rutstrom and Tarr (1995) and Konan and Maskus (2000). The trade elasticities are 2.0 for substitution between domestic and imported goods, 5.0 for substitution among regional imports and for transformation between domestic output and exports, and 8.0 for transformation among regional export destinations. We also assume that the trade elasticities are 0.5 for services.

\subsection{Impact of Telecom Liberalization}

To estimate the impact of telecom liberalization in Tunisia, we analyze the effect of allowing a single foreign provider to enter Tunisia's telecom market. We only focus on the entry of one foreign provider for two reasons. First, given that we have no information on the size of the fixed cost that a foreign entrant would face in the Tunisian telecom market, we cannot determine how many providers would be able to enter in free-trade equilibrium. Second, as Low and Mattoo (2000) have indicated, recent service liberalization discussions have focused primarily on freeing up ownership restrictions rather than necessarily allowing free entry per se. As a result, there is a strong policy and academic interest in understanding the impact of partial service trade liberalization where only few firms are allowed to enter a service sector.

We define the counterfactual telecom liberalization scenarios through a combination of three factors. First, depending on the regulatory environment, the foreign provider and the domestic incumbent can form two different market structures. If the regulatory environment is sufficiently procompetitive, we assume that both providers compete in quantities (Cournot duopoly). If the regulatory environment is not sufficiently pro-competitive, the two providers form a cartel. In that case, the foreign entrant is assumed to set its price equal to the price that the domestic incumbent initially charged for its services, thus splitting up the market in half. Second, the foreign provider does not necessarily face the same cost structure as the domestic incumbent. To take this into account, we assume that the foreign entrant may face one of two marginal costs. On the one hand, he may face the same marginal cost as the domestic incumbent (symmetric costs). In this case, the foreign entrant also faces a marginal cost that is $15 \%$ above the world's best-practice marginal cost. On the other hand, he may face a

lower marginal cost than the domestic incumbent (asymmetric costs). In 
that case, the foreign entrant does not face the cost-inefficiency wedge that the domestic incumbent faces, but rather faces the world's best-practice marginal cost. This implies that the foreign entrant is $15 \%$ more efficient than the domestic incumbent. Finally, the foreign firm does not necessarily shift all of its profits to the domestic representative agent. In our counterfactual scenarios, we focus on the two extremes where the foreign entrant shift all of its profits abroad or shift all of its profits to the domestic representative agent.

By combining these three factors, we end up with $2^{3}=8$ counterfactual scenarios. In Table 2, we depict the impact of telecom liberalization on the performance of the telecom sector, the macro-economy and on household welfare for these 8 counterfactual telecom liberalization scenarios.

\section{[Table 2 about here]}

Scenario 1 in Table 2 depicts the telecom liberalization scenario where an equally efficient foreign entrant competes in quantities with the domestic incumbent and transfers its profits to the domestic representative agent. In this case, the composite price of telecom services drops by 0.07 percent and the telecom sector's output grows by 18.31 percent. The entry of the foreign provider leads to a slight expansion of the Tunisian economy, with real Gross Domestic Product (GDP) increasing by 0.15 percent. Due to a reduction of the consumer price index (CPI) by 0.19 percent, the economic expansion is export-led, with aggregate exports growing 2.49 percent. The benefits of telecom liberalization accrue primarily to labor, with returns to labor increasing by 0.37 percent and returns to capital increasing 0.10 percent. Overall, household welfare (measured as Hicksian-neutral equivalent variation) improves by 0.19 percent. This is a significant increase in household welfare given that we are considering liberalization of just one sector, and in a static context.

Scenario 2 in Table 2 also depicts a scenario where an equally efficient foreign entrant competes in quantities with the domestic incumbent. Counter to scenario 1, however, the foreign entrant shifts all of its profits abroad instead of to the domestic representative agent. Profit shifting does not have a significant impact on the size and type of economic expansion. The telecom sector expands 18.31 percent, while Tunisia's real GDP and exports increase by 0.14 percent and 2.49 percent, respectively. However, profit shifting does lead to a significantly lower growth of household welfare. In contrast to the 0.19 percent growth of household welfare in the absence of profit shifting 
(scenario 1), the negative profit shifting effect induces household welfare to grow an insignificant 0.02 percent.

In scenario 3 , a foreign entrant with a 15 percent lower marginal cost competes in quantities with the domestic incumbent and transfers its profits to the domestic representative agent. The entry of a more efficient foreign provider leads to a more robust expansion of the Tunisian economy than the entry of an equally efficient foreign provider (scenario 1 ). In this case, the composite price of telecom services drops by 0.15 percent and the telecom sector's output grows by 53.06 percent. The Tunisian economy has a more solid economic growth, with real GDP increasing by 0.47 percent. Due to a significant reduction of the CPI by 0.59 percent, aggregate exports grow 6.99 percent. The benefits of telecom liberalization once again accrue primarily to labor, with returns to labor increasing by 0.80 percent and returns to capital increasing 0.29 percent. In contrast to the 0.19 percent growth of household welfare when an equally efficient foreign provider enters (scenario 1), the positive efficiency effect induces household welfare to grow a more solid 0.65 percent.

In scenario 4, a more efficient foreign entrant competes in quantities with the domestic incumbent and shifts all of its profits abroad. When compared to scenario 3, profit shifting once again only has a limited impact on the size and type of economic expansion. The telecom sector expands 53.06 percent, while Tunisia's real GDP and exports increase by 0.44 percent and 6.99 percent, respectively. However, profit shifting does lead to a significantly lower growth of household welfare. In contrast to the 0.65 percent growth of household welfare in the absence of profit shifting (scenario 3 ), the negative profit shifting effect induces household welfare to grow only 0.26 . When compared to scenario 2, having a more efficient foreign provider entering the market leads to both a stronger GDP and household welfare growth than having an equally efficient foreign provider entering the market. While household welfare only grows 0.02 percent when an equally efficient foreign provider enters the market (scenario 2), the positive efficiency effect induces household welfare to grow 0.26 .

In scenario 5, an equally efficient foreign entrant colludes with the domestic incumbent by setting its price equal to the domestic monopolist's original price. The foreign entrant transfers its profits to the domestic representative agent. There are two new insights that this scenario provides. First, the absence of a positive pro-competitive effect implies that the economic expansion and welfare improvement is lower than when both equally efficient providers compete in quantities (scenario 1). Second, despite the fact that both providers form a cartel by both charging the domestic monopoly price, 
there is still a small economic expansion and welfare gain due to the fact that both providers sell different varieties of telecom services (love-of-variety effect). As a result, Tunisia's real GDP and household welfare grow by 0.11 percent and 0.15 percent respectively.

In scenario 6 , an equally efficient foreign entrant colludes with the domestic incumbent and shifts all of its profits abroad. The absence of a positive pro-competitive effect once again implies that the economic expansion and welfare improvement is lower than when two equally efficient providers compete in quantities (scenario 2). The telecom sector expands 8.37 percent, while Tunisia's real GDP and exports increase by 0.08 percent and 1.19 percent, respectively. In addition, when compared to scenario 5, profit shifting leads to a significantly lower growth of household welfare than when profits are transferred to the domestic representative agent. In contrast to the 0.15 percent growth of household welfare in the absence of profit shifting (scenario 5), the negative profit shifting effect implies that household welfare REDUCES 0.25 percent. This is an important result since it implies that partial telecom liberalization in Tunisia does not necessarily improve the country's welfare.

In scenario 7, a more efficient foreign entrant colludes with the domestic incumbent and transfers its profits to the domestic representative agent. When compared to scenario 5 , the entry of a more efficient foreign provider leads to a more robust expansion of the Tunisian economy and a positive efficiency effect on household welfare. The composite price of telecom services drops by 0.04 percent and the telecom sector's output grows by 8.47 percent. The Tunisian economy has a more solid economic growth, with real GDP increasing by 0.36 percent and aggregate exports growing 1.50 percent. Overall, household welfare improves by 0.54 percent. Due to the absence of a pro-competitive effect, the welfare gain is lower than in scenario 3 where the domestic incumbent and the more efficient foreign entrant compete in quantities.

In scenario 8, a more efficient foreign entrant colludes with the domestic incumbent and shifts all of its profits abroad. In this scenario, there is a negative profit shifting effect, there is no positive pro-competitive effect and there is a positive efficiency effect. As a result, the telecom sector expands 8.47 percent, while Tunisia's real GDP and exports increase by 0.31 percent and 1.50 percent, respectively. Once again, the fact that the foreign entrant colludes with the domestic incumbent and shifts its profits abroad implies that Tunisia's welfare declines by 0.21 percent.

From Table 2, the best-case scenario occurs when a more efficient foreign provider strategically competes in quantities with the domestic incumbent 
and transfers its profits to the domestic representative agent (scenario 3). The reason for this is straightforward: in this case, there is a positive efficiency and pro-competitive effect, while there is no negative profit-shifting effect. As a result, household welfare improves by 0.65 percent. Under the worst-case scenario, an equally efficient foreign provider colludes with the domestic incumbent and shifts its profits abroad (scenario 6). In this case, there are no welfare-improving pro-competitive or efficiency effects, while the welfare-reducing profit shifting effect occurs. As a result, household welfare is estimated to worsen 0.25 percent.

We can gain further insights into the the welfare differences between the various counterfactual scenarios by decomposing the total welfare gains into the four individual welfare effects identified in Section 2: (i) love-of-variety effect, (ii) pro-competitive effect, (iii) efficiency effect and (iv) profit shift-

ing effect. We can calculate the size of these individual effects by measuring the change in welfare gain if an individual effect is removed. Consider, for example, scenario 4 where a more efficient foreign entrant competes in quantities with the domestic incumbent and transfers its profits abroad. Under this scenario, the pro-competitive effect, efficiency effect and profit-shifting effect all are present. One can then determine the size of the profit-shifting effect by calculating how much welfare goes down if the more efficient foreign entrant transfers its profits to the domestic representative agent instead of abroad (Scenario 3). It is straightforward to calculate that the profit shifting effect is -0.39 percent. Similarly, one can determine that the pro-competitive effect is 0.47 percent by calculating how much welfare goes down if the more efficient foreign entrant colludes with the domestic incumbent instead of competing (Scenario 8). The size of the efficiency effect can be determined to be 0.24 percent by calculating how much welfare goes down if the foreign entrant is equally efficient than the domestic incumbent instead of more efficient (Scenario 2). Finally, if we subtract the sum of the pro-competitive effect, efficiency effect and profit-shifting effect from the total welfare effect, we find a residual effect of -0.06 . This residual effect can be attributed to two factors: the unambiguously positive love-of-variety effect and interaction effects.

\section{[Table 3 about here]}

In Table 3, we have decomposed the total welfare effect of each counterfactual scenario into its individual effects. The individual welfare effects all take on their expected signs: the pro-competitive and efficiency effect are 
always positive and the profit-shifting effect is always negative. The size of the effects varies significantly between scenarios. The pro-competitive effect ranges from $0.04 \%$ to $0.47 \%$; the efficiency effect from $0.04 \%$ to $0.46 \%$; and the profit-shifting effect from $-0.75 \%$ to $-0.17 \%$. Since none of the effects dominate in magnitude, it is not possible to a single out an individual effect that should be targeted during telecom liberalization.

Telecom liberalization does not have a symmetric impact across industries, but rather induces some industries to expand and others to contract. In Table 4, we depict the impact of telecom liberalization on sectoral output. In order to ease comparison with Table 1, the industries are ranked in descending order according to their telecom usage intensity. A first thing to note is that the impact of telecom liberalization on sectoral output is very similar in sign and relative ranking across the counterfactual scenarios. In all scenarios, "Business" is the biggest winner and "Restaurant" the biggest loser from telecom liberalization. In all scenarios, the winners and losers are ranked the same relative to one another. A second thing to note is that five of the six fastest growing sectors are the five producer services sectors (business, telecommunication, insurance, transportation and finance). Real estate, repair, petroleum \& gas, apparel and electric materials close off the top ten expanding sectors. Generally, the expanding sectors are laborintensive industries with high telecom and producer-service intensity. The three industries that contract the most are restaurant, leather and health \& education.

\section{[Table 4 about here]}

\subsection{Sensitivity Analysis}

In our counterfactual scenarios, we have made strong assumptions about the share of profits that the foreign provider shifts abroad. In scenarios 1, 3,5 and 7 , we assumed that the foreign provider shift none of their profits abroad; in scenarios 2, 4, 6 and 8, we assumed that the foreign provider shifts all of its profits abroad. To investigate the role that profit shifting plays on the impact of telecom liberalization, we have conducted a sensitivity analysis in which we allow the share of profits shifted abroad by the foreign entrant to vary. In Table 5, we report the results of the sensitivity analysis. Note that when the foreign firm shifts $0 \%$ of its profits abroad, it corresponds to the "profit retention" scenarios in Table 2. When the foreign firm shifts 100 
percent of its profits abroad, it corresponds to the "profit shifting" scenarios in Table 2.

\section{[Table 5 about here]}

The results in Table 5 demonstrate that the welfare gain of telecom liberalization in Tunisia strictly decreases with the share of profits that the foreign provider shifts abroad. In all four columns, the welfare gain from telecom liberalization decline as the share of profits that the foreign provider shifts abroad increases. The results depicted in Table 5 also shed light on the minimum share of profits that the foreign provider needs to shift abroad in order to create a welfare loss. In a symmetric cartel, telecom liberalization will be welfare reducing if more than 40 percent of the profits are shifted abroad. This implies that a welfare loss from telecom liberalization can occur even if only a moderate share of profits is shifted abroad. Under an asymmetric cartel, telecom liberalization will be welfare reducing if more than 80 percent of profits are shifted abroad.

Since we do not have sufficient information to determine the relative size of the cartel wedge and cost inefficiency wedge, we have also made a strong assumption that both wedges are equally weighted. To investigate the role of the relative size of both wedges on our estimation results, we have presented in table 6 the results of a second sensitivity analysis in which the share of the cartel wedge in the total-price cost wedge is allowed to vary.

\section{[Table 6 about here]}

As is shown in Table 6, the cartel wedge share does not have a straightforward impact on welfare. In scenario 1, welfare increases as the cartel wedge share increases; in scenario 3, welfare decreases as the cartel wedge share increases; in scenario 5 , welfare is not affected by the cartel wedge share. To understand the impact of the cartel wedge share on total welfare, it is therefore important to understand its impact on the individual welfare effects. First, an increase in the cartel wedge share implies that competitive foreign entry can have a larger impact, thus leading to a larger pro-competitive effect. This can explain why in scenario 1 the welfare gains related to service trade liberalization increases with the cartel wedge share, while in scenario 5 , welfare remains unchanged. Second, since an increase in the cartel wedge share automatically reduces the cost inefficiency wedge share, this implies 
that the efficiency effect becomes smaller. This can explain why in scenario 7 the welfare gains related to service trade liberalization is unambiguously decreasing with the cartel wedge share. Finally, the impact of the cartel wedge share on the profit-shifting effect is unclear (see scenario 6).

\section{Conclusion}

Recent academic and policy studies have uncovered a link between the success of service trade liberalization and issues of market structure and domestic regulation. CGE studies, however, have faced significant theoretical hurdles to quantify these links. In this paper, we have set a first step to bridge these hurdles by introducing a method to incorporate a single imperfectly competitive service sector that can take on various market structures into a standard CGE model. We have identified that service trade liberalization can induce four welfare effects in such a framework. It can induce a positive love-of-variety effect if services provided by domestic and foreign providers are considered to be imperfect substitutes. It can lead to a positive pro-competitive effect if the two providers decide to compete in quantities instead of colluding. It can induce a positive efficiency effect if the foreign providers are more efficient than the domestic provider. Finally, it can lead to a negative profit-shifting effect if the foreign providers shift their profits abroad. The fact that the welfare effects have different signs corresponds to policy and academic concerns that the welfare impact of service trade liberalization is ambiguous and depends on the adopted market structure and country characteristics.

In the second part of the paper, we have introduced our framework into a CGE model for Tunisia to quantify the welfare impact of allowing one foreign provider to enter Tunisia's telecommunication sector. According to our conservative estimates, the welfare implications are clearly positive if competition can be guaranteed between providers. Welfare gains can be up to 0.65 percent if the foreign provider is 15 percent more efficient than the domestic incumbent and does not shift its profits abroad. This can be considered a significant gain in household welfare, since we are modelling the liberalization of a single sector in a static context. In contrast, telecom liberalization will be welfare deteriorating if the foreign provider colludes with the domestic incumbent and shifts a significant portion of its profits

abroad. Our results thus call for Tunisia among other developing countries to step up its pro-competitive regulatory reforms while liberalizing its telecom sector. 
By deriving the Lerner markup conditions for one imperfectly services sector, our framework has set a first step to analyze the role of market structure on the success of service trade liberalization. These Lerner markup conditions do not easily generalize, however, to a framework with multiple imperfectly competitive services sectors. Our approach thus cannot be used to analyze the welfare impact of multi-sector service trade liberalization. For multi-sector service trade liberalization, the approach suggested by Konan and Maskus (2006) continues to be the preferred approach. Future research is needed to derive the Lerner markup conditions in a framework with multiple imperfectly competitive services sectors.

Finally, with more information concerning fixed costs and licensing fees in a country's service sector, we would be able to do a richer analysis of the role of market structure in the success of a service trade liberalization in a single sector. Specifically, we would be able to compare the welfare impact of partial service trade liberalization where only few players are allowed to enter a market to complete service trade liberalization where the service sector becomes monopolistically competitive. 


\section{Appendix A: General Equilibrium Lerner Markup Condition}

Hoffmann (2002) uses three equations to derive the general equilibrium Lerner markup condition when a firm faces different buyers. To simplify notation in this appendix, we will drop the subscript $j$ so that $z_{i}$ represents the amount of services that provider $j$ allocates to sector $i$.

First, the following arbitrage condition needs to hold for firm $j$ :

$$
\frac{\partial p}{\partial z_{i}} d z_{i}=\frac{\partial p_{z}}{\partial z_{l}} d z_{l}
$$

where $p$ is the price that the service provider charges for its services. By converting the partials in equation (A-1) to inverse price elasticities and rearranging:

$$
d z_{i}=\frac{\Phi_{i}}{\Phi_{l}} \frac{z_{i}}{z_{l}} d z_{l}
$$

where $\Phi_{i}=-\frac{\partial z_{i}}{\partial p} \frac{p}{z_{i}}$. If we sum equation (A-2) over all uses:

$$
\sum_{i} d z_{i}=\sum_{i} \frac{\Phi_{i}}{\Phi_{l}} \frac{z_{i}}{z_{l}} d z_{l}
$$

A second necessary equation states that changes in a provider's total supply $z$ equals the sum of the changes in the supply to all the buyers:

$$
d z=\sum_{i} d z_{i}
$$

By combining equations (A-3) and (A-4):

$$
d z_{l}=\left[\frac{\Phi_{l} z_{l}}{\sum_{i} \Phi_{i} z_{i}}\right] d z
$$

A final necessary equation is the total derivative of the profit equation for firm $z$ :

$$
(p-c) \sum_{i} d z_{i}+\sum_{i} z_{i} \frac{\partial p}{\partial z_{i}} d z_{i}=0
$$

If we incorporate equations (A-4) and (A-5) into equation (A-7):

$$
(p-c) d z-p \frac{\sum_{i} z_{i}}{\sum_{i} \Phi_{i} z_{i}} d z=0
$$


This leads us to the general equilibrium Lerner markup condition:

$$
p\left[1-\frac{1}{\sum_{i} \Phi_{i} \theta_{i}}\right]=c
$$

where $\theta_{i}=\frac{z_{i}}{\sum_{i} z_{i}}$. It can be useful to distinguish final good usage from intermediate good usage since the derivation of the demand elasticity will be different:

$$
p\left[1-\frac{1}{\Phi_{u} \theta_{u}+\sum_{i} \Phi_{i} \theta_{i}}\right]=c
$$

where $\Phi_{u}$ equals the consumers' demand elasticity for the provider's services; $\theta_{u}$ equals the share of the provider's services that is sold to consumers; $\Phi_{i}$ equals the demand elasticity for the provider's telecom services by sector $i$ and $\theta_{i}$ equals the share of the provider's services that is sold to sector $i$. 


\section{Appendix B: Demand elasticity for intermediate in- puts}

As we have demonstrated in equation (8), the price of service $p_{j}$ can be derived from the chain rule:

$$
p_{j}=P_{y, i} \frac{\partial Y_{i}}{\partial Y_{z, i}^{x}} \frac{\partial Y_{z, i}^{x}}{\partial z_{j, i}}
$$

Since final good output $Y_{i}$ and composite producer services $P S_{i}$ have a Leontief technology, the cost share of $V_{i}$ in the production of $Y_{i}$ is $\lambda_{v, i}$ and the cost share of $Y_{z, i}$ in the production of $P S_{i}$ is $\kappa_{z, i}$. Therefore,

$$
\begin{gathered}
Y_{i}=\frac{V_{i}}{\lambda_{v, i}} \\
P S_{i}=\frac{Y_{z, i}}{\mu_{z, i}}
\end{gathered}
$$

By inserting equations (B-3) and (C-3) into equation (B-2):

$$
Y_{i}=\frac{\left[\left(K_{i}^{\alpha_{i}} L_{i}^{\beta_{i}}\right)^{\gamma}+\left(\frac{Y_{z, i}}{\mu_{z, i}}\right)^{\gamma}\right]^{\frac{1}{\gamma}}}{\lambda_{v, i}}
$$

From equation (B-4), we can derive:

$$
\frac{\partial Y_{i}}{\partial Y_{z, i}}=\frac{1}{\kappa_{z, i} \lambda_{v, i}}\left[\left(L_{i}^{\alpha_{i}} K_{i}^{\beta_{i}}\right)^{\gamma}+\left(\frac{Y_{z, i}}{\kappa_{z, i}}\right)^{\gamma}\right]^{\frac{1-\gamma}{\gamma}}\left(\frac{Y_{z, i}}{\kappa_{z, i}}\right)^{\gamma-1}
$$

Next, we need to derive $\frac{\partial Y_{z, i}^{x}}{\partial z_{j, i}}$. This will depend on sector $Y_{z}$ 's market structure. If there is a monopoly, then a single provider is operating in the market and thus $\frac{\partial Y_{z, i}^{x}}{\partial z_{j, i}}=1$. Under a Cournot oligopoly, each provider assumes that the other providers will leave output unchanged when it changes its output. In a cartel, all providers collaborate by setting prices to maximize joint profits. We assume that collaboration only can be enforced if the providers collude set the same price $p_{d}=p_{f}$. Since there is a constant elasticity of substitution between both services, this implies that all providers produce the same amount of services, i.e. $z_{d}=z_{f}$. From equation (C-1), we can 
then derive:

$$
\frac{\partial Y_{z, i}^{x}}{\partial z_{j, i}}=\left\{\begin{array}{lll}
1 & \text { if } & \text { monopoly } \\
n^{\frac{1}{\epsilon}} & \text { if } & \text { cartel } \\
\left(\sum_{i}^{n} z_{i j}^{\epsilon}\right)^{\frac{1-\epsilon}{\epsilon}} z_{i j}^{\epsilon-1} & \text { if } \text { duopoly } \\
0 & \text { if monopolistic competition }
\end{array}\right.
$$

The service provider's price $p_{j}$ can be derived by inserting the equation above and equation (B-5) into equation (B-1). 


\section{Appendix C: Full Description of the CGE Model}

In this Appendix, we will list the main equations of the model. For a full list of all identities, please refer to Konan (2003).

Consider a CGE model with $I-1$ perfectly competitive sectors that produce output $Y_{i}$ and one imperfectly competitive producer service sector that provides service $Y_{z}$. Sectoral output is used both as an intermediate good by sectors $I$ and as a final good by the representative consumer. We denote intermediate good use by superscript $x$ and final good use by superscript $c$. In the imperfectly competitive producer service sector $Y_{z}, N$ service providers each produce a single differentiated service $z_{j}$. The service providers are not necessarily symmetric and can be both domestic and foreign. Users perceive a constant elasticity of substitution between each provider's service, and we thus represent total industry output $Y_{z}$ as a CES function of services provided by each provider $z_{j}$ :

$$
Y_{z}=\left(\sum_{j=1}^{N} z_{j}^{\epsilon}\right)^{\frac{1}{\epsilon}}
$$

The elasticity of substitution between each variety is $\sigma=\frac{1}{1-\epsilon}$, where $\sigma>1$.

Producer service sector $Y_{z}$ is one of a select group of $H$ producer services that positively affect value-added productivity when used as an intermediate good (Markusen et al., 2005). Telecommunications, finance, insurance, business services and transportation are generally considered to belong to this category. To model this, we assume that industry $i \in I$ 's composite producer services $P S_{i}$ is a Leontief function of the share of producer service sector $H$ 's output allocated to sector $i$ :

$$
P S_{i}=\min \left[\frac{Y_{1, i}^{x}}{\kappa_{1, i}}, \ldots, \frac{Y_{H-1, i}^{x}}{\kappa_{H-1, i}}, \frac{Y_{z, i}^{x}}{\kappa_{z, i}}\right] .
$$

Composite producer services $P S_{i}$ are an imperfect substitute to value added $K_{i}^{\alpha_{i}} L_{i}^{\beta_{i}}$ in that industry:

$$
V_{i}=\left[\left(K_{i}^{\alpha_{i}} L_{i}^{\beta_{i}}\right)^{\gamma}+P S_{i}^{\gamma}\right]^{\frac{1}{\gamma}}
$$

where the constant elasticity of substitution between value added and producer services is $\rho=\frac{1}{1-\gamma}$. We call function $V_{i}$ composite value added of industry $i$. The production function for all sectors except for $Y_{z}$ is approximated with Leontief technologies using composite intermediate inputs from 
$i \notin H$ and composite value added $V$ allocated to the industry.

$$
Y_{i}=\min \left[\frac{Y_{H+1, i}^{x}}{\lambda_{H+1, i}}, \ldots, \frac{Y_{I, i}^{x}}{\lambda_{I, i}}, \frac{V_{i}}{\lambda_{v, i}}\right] .
$$

Similarly, The Leontief production function for firm $j$ in sector $Z$ takes the following form:

$$
z_{j}=\min \left[\frac{Y_{H+1, j}^{x}}{\lambda_{H+1, j}}, \ldots, \frac{Y_{I, j}^{x}}{\lambda_{I, j}}, \frac{V_{j}}{\lambda_{v, j}}\right] .
$$

In export sectors, the production for the domestic market $D_{i}$ is distinguished from that for export $E X_{i}$ according to a two-tier nested constant elasticity of transformation (CET) frontier:

$$
Y_{i}=\left[\delta_{D, i} D_{i}^{\frac{\zeta_{i}-1}{\zeta_{i}}}+\delta_{E X, i} E X_{i}^{\frac{\zeta_{i}-1}{\zeta_{i}}}\right]^{\frac{\zeta_{i}}{\zeta_{i}-1}} .
$$

The second-tier CET-nest aggregates total exports, $X_{i}$, from exports by destination, $E X_{r i}$, indexed by $r$ (EU, MENA, and ROW):

$$
E X_{i}=\left[\sum_{r} \eta_{i, r} E X_{i, r}^{\frac{\kappa_{i}-1}{\kappa_{i}}}\right]^{\frac{\kappa_{i}}{\kappa_{i}-1}} .
$$

In sector $l$, intermediate good demand $x_{i, l}$ and final demand $c_{l}$ is differentiated by country of origin. Domestic output $D_{l, i}$ and $D_{l, c}$, and region $r$ imports, $I M_{r, l, i}$ and $I M_{r, l, c}$ are aggregated in the following nested Armington CES functions:

$$
x_{l, i}=\left[\lambda_{D, l} D_{l, i}^{\frac{\mu_{l}-1}{\mu_{l}}}+\lambda_{I M, l} I M_{l, i}^{\frac{\mu_{l}-1}{\mu_{l}}}\right]^{\frac{\mu_{l}}{\mu_{l}-1}}
$$

and

$$
C_{l}=\left[\nu_{D, l} D_{l, C}^{\frac{\xi_{l}-1}{\xi_{l}}}+\nu_{I M, l} I M_{l, C}^{\frac{\xi_{l}-1}{\xi_{l}}}\right]^{\frac{\xi_{l}}{\xi_{l}-1}},
$$

where composite intermediate imports $I M_{l, i}$ and final imports $I M_{l, C}$, are given by the following:

$$
I M_{l, i}=\left[\sum_{r} \varpi_{l, r} I M_{l, i, r}^{\frac{\psi_{i}-1}{\psi_{i}}}\right]^{\frac{\psi_{i}}{\psi_{i}-1}}
$$

and

$$
I M_{l, C}=\left[\sum_{r} \varpi_{l, r} I M_{l, C, r}^{\frac{\psi_{i}-1}{\psi_{i}}}\right]^{\frac{\psi_{i}}{\psi_{i}-1}} .
$$


In all sectors except for the telecommunications sector, firms face constant returns to scale and behave competitively, implying that prices $p_{y, l}$ equal marginal cost $c_{l}$, for output within sector $l$. The domestic policy environment is reflected by government-revenue-producing tariffs on sector $l$ imports from region $r, t_{l, r}$ and a tax on primary input value added, $\tau_{l}$

$$
c_{l} Y_{l}=\sum_{l} p_{l} D_{l, i}+\sum_{l} \sum_{r}\left(1+t_{l, r}\right) p_{y, l, r}^{i m} I M_{l, i, r}+\left(w_{K} K_{i}+w_{L} L_{i}\right)
$$

In the imperfectly competitive telecom sector, the domestic and foreign firm face the following Lerner markup condition:

$$
p_{j}^{k}=\frac{\sum_{j}^{k}}{\sum_{j}^{k}-1} c_{j}(w, r),
$$

where

$$
\begin{gathered}
\Sigma_{j}^{k}=\left(\frac{\omega_{u}}{1-\epsilon\left(1-s_{j}^{k}\right)}+\sum_{i} \frac{\omega_{y, i}}{\left(1-s_{j}^{k}\right)(1-\epsilon)+s_{v, i} s_{j}^{k}(1-\gamma)}\right) \\
s_{v, i}=\frac{p_{v, i}^{1-\rho}}{p_{v, i}^{1-\rho}+p_{p s, i}^{1-\rho}}
\end{gathered}
$$

and the market share of provider $j$ equals

$$
s_{j}=\frac{p_{j}^{1-\sigma}}{\sum_{j=1}^{N} p_{j}^{1-\sigma}} .
$$

The price of the composite service $Z$ then becomes:

$$
P_{z}^{k}=\left(\sum_{j} p_{j}^{k^{1-\sigma}}\right)^{\frac{1}{1-\sigma}}=\left(\sum_{j}\left(\frac{\sum_{j}^{k}}{\sum_{j}^{k}-1} c_{j}(w, r)\right)^{1-\sigma}\right)^{\frac{1}{1-\sigma}} .
$$

In the model, private household expenditures are determined by a representative agent with a multi-nested CES utility function. This allows the agent to make separable multi-staged budget decisions. In the top-tier budgeting decision the income elasticity is assumed to be unity with a Cobb-Douglas nested utility function:

$$
U=\Pi_{i} C_{i}^{b i}, \quad \text { with } \sum_{i} b_{i}=1 .
$$


The second budgeting stage involves the consumer deciding how much to spend on domestic versus imported commodities, which is determined in equations (C-8)-(C-11).

Private households receive income generated by returns to endowments of labor, $\bar{E}_{L}$, and other value added, $\bar{E}_{K}$. Households receive monopoly rent transfers from the domestic telecom incumbent $\pi_{d} z_{d}$ and under some scenarios from the multinational telecom provider $\pi_{m} z_{m}$. Households support a government budget deficit, $D$, and engage in savings through exogenously fixed investment instruments, $I_{i}$.

$\sum_{i} \tilde{p}_{i}^{C} C_{i}=w_{K} \bar{E}_{K}+w_{L} \bar{E}_{L}-\sum_{i} p_{i} I_{i}^{I}-\sum_{i} \tilde{p}_{i}{ }^{I F} I_{i}^{F}-r^{F} K^{F}-D+\pi_{d} z_{d}+\pi_{m} z_{m}$

The model simplifies the treatment of government and intertemporal decisions. The government is assumed to spend based on a fixed real income, with preferences reflecting those of households. A lump-sum tax adjusts endogenously in response to policy shocks to maintain a revenue-neutral government budget.

$$
\sum_{i} \tilde{p}_{i}^{G} G_{i}=D+\sum_{i} \tau_{V i} \tilde{p}_{i}^{C} V_{i}+\sum_{i} \sum_{r} t_{i, r} p_{i, r}^{i m}\left(I M_{i, C, r}+I M_{i, I, r}^{F}\right)
$$

Similarly, real private investment in each sector, $I_{i}$, is exogenously fixed at the benchmark level.

As noted above, import and export prices are exogenous following the small-economy assumption. The real current account balance, $B$, is exogenously given at international prices and is assumed to be exogenous. That is, the volume of trade adjusts endogenously to ensure a constant real current account. The balance of payments conditions also holds.

$$
\begin{aligned}
B & =\sum_{i} \sum_{r} p_{r, i}^{e x} E X_{r, i}-\sum_{i} \sum_{l} \sum_{r} p_{r, i}^{i m} I M_{r, i}^{l}-\sum_{i} \sum_{r} p_{r, i}^{i m} I M_{r, i}^{C} \\
0 & =\sum_{r} \sum_{i} \frac{1}{e}\left(p_{r, i}^{i m} I M_{r, i}-p_{r, i}^{e x} E X_{r, i}-w_{L}^{F} L^{F}-r^{F} K^{F}-\pi_{m} z_{m}\right)
\end{aligned}
$$

It is important to note that key identities hold as the optimizing behavior of agents assures that income will equal expenditures. Market clearance is achieved in each goods market, each factor market and the total supply value in the economy is balanced.

$$
S_{i}=\sum_{l} a_{l, i} Y_{l}+G_{i}+I_{i}^{F}+I_{i}^{I}+C_{i}
$$




$$
\begin{gathered}
\sum_{i} K_{i}=\bar{E}_{K} ; \quad \sum_{i} L_{i}=\bar{E}_{L} \\
\tilde{p}_{i} S_{i}=\tilde{p}_{i}^{Z} \sum_{l} a_{i, l}\left(1+v_{i}\right) Y_{l}+\tilde{p}_{i}^{C} D_{i, C}+\tilde{p}_{i}^{I F} D_{i, I}^{F}+\tilde{p}_{i}^{G} D_{i, G}+\quad(\mathrm{C}-24) \\
\tilde{p}_{i}^{I F} I_{i}^{I}+\sum_{r}\left(1+\tau_{V, i}+u_{i}+t_{i, r}\right) p_{i, r}^{i m}\left(I M_{i, C, r}+I M_{i, G, r}+I M_{i, I, r}^{F}\right)
\end{gathered}
$$

In this Arrow-Debreu type model, Walras' law is satisfied and, given a numeraire, a unique set of real prices is determined in each scenario. 
Table C-1: List of Variables

\begin{tabular}{ll}
\hline$B$ & Current-account balance \\
$c_{i}$ & Index of marginal cost of production \\
$C_{i}$ & Private consumption \\
$D$ & Government budget deficit \\
$D_{i j}$ & Domestic sales in sector $i$ used by $j$ \\
$e$ & Real exchange rate (price index for foreign exchange) \\
$E X_{i r}$ & Exports in sector $i$ to region $r$ \\
$G_{i}$ & Public consumption \\
$I_{i}^{F}, I_{i}^{I}$ & Fixed capital formation and inventory \\
$I M_{i j r}$ & Imports in sector $i$ from region $r$ used in $j$ \\
$K^{F}$ & Net payments on foreign capital holdings \\
$K_{i}$ & Non-labor (capital) inputs \\
$L_{i}$ & Domestic labor inputs \\
$p_{i}$ & Domestic producer price index \\
$p_{i}^{j}$ & Price index of domestic goods used by $j$ \\
$p_{i r}$ & Producer price index for goods exported to region $r$ \\
$p_{i j r}$ & Domestic price index for imports in sector $i$ from region $r$ used in $j$ \\
$\tilde{p}_{i}$ & Composite price index for total domestic supply \\
$\tilde{p}_{i j}$ & Composite price index (weighted average of home and imported prices) \\
$P S_{i}$ & Producer services \\
$S_{i}$ & Supply on domestic market \\
$U$ & Utility of representative consumer \\
$V_{i}$ & Value added \\
$w_{K}, w w_{L}$ & Factor price indexes \\
$x_{i j}$ & Composite intermediate input of $j$ into $i$ \\
$Y_{i}$ & Output of good $i$ \\
$Z_{D}$ & Telecom services provided by domestic incumbent \\
$Z_{M}$ & Telecom services provided by foreign entrant \\
$\theta_{i}$ & Share of total telecom services used by $i$ \\
$\rho$ & Elasticity of substitution between value added and producer services \\
$\tau_{V i}$ & Endogenous tax rate on value added \\
$\phi_{i}$ & Elasticity of demand for telecom user $i$ \\
\hline &
\end{tabular}


Table C-2: List of Parameters

\begin{tabular}{ll}
\hline$\alpha_{i}$ & Labor share of value added in sector $i$ \\
$\beta_{i}$ & Non-labor share of value added \\
$\gamma$ & $\frac{\rho-1}{\rho}$ \\
$\epsilon$ & $\frac{\sigma-1}{\sigma}$ \\
$\zeta_{i}$ & Transformation elasticity between domestic and exported output \\
$\kappa_{i}$ & Transformation elasticity on exports between regions \\
$\lambda_{i}$ & Service resource-using barriers on output $\left(\lambda_{i}=0\right.$ for non-service sectors $)$ \\
$\mu_{j}$ & Substitution elasticity between domestic and imported intermediates \\
$\xi_{j}$ & Substitution elasticity between domestic and imported consumption \\
$\pi_{i}$ & Telecom rents for service provider $i$ \\
$\sigma$ & Elasticity of substitution between domestic and foreign telecom services \\
$\psi_{i}$ & Armington elasticity on imports between regions \\
$\bar{E}_{K}, \bar{E}_{L}$ & Endowments of capital and labor \\
$p_{i r}^{i m}$ & Price of imports from region $r$ \\
$p_{i r}^{e x}$ & Price of exports to region $r$ \\
$r F$ & Price of foreign capital payments \\
$t_{i r}$ & Tariff rate on imports from region $r\left(t_{r i}=0\right.$ for service sectors $)$ \\
$u_{i}$ & Resource-using services border barriers $\left(u_{i}=0\right.$ for non-service sectors $)$ \\
\hline
\end{tabular}




\section{References}

[1] Arnold J., Javorcik B., Mattoo A., 2006. The productivity effects of services liberalization: evidence from the Czech Republic," mimeo.

[2] Brown D., Deardorff A., Fox A., Stern R., 1996. Computational analysis of goods and services liberalization in the Uruguay Round. In Martin W., Winters A. (Eds). The Uruguay Round and the Developing Economies. Cambridge University Press: New York, D.C., 1996.

[3] Brown D., Deardorff A., Stern R., 1997. Some economic effects of the free trade agreement between Tunisia and the European Union," In: Galal A., Hoekman B. (Eds), Regional partners in global markets: limits and possibilities of the Euro-Med agreements. Centre for Economic Policy Research: London, 1997.

[4] Brown D., Stern R., 2001. Measurement and modeling of the economic effects of trade and investment barriers in services. Review of International Economics 9, 262-286.

[5] Chatti R., 2000. General equilibrium assessment of trade liberalization effects under Cournot oligopoly market structures: the case of Tunisia. Economic research forum for the Arab countries, Iran and Turkey, working paper 2009.

[6] Copeland B., 2002. Benefits and costs of trade and investment liberalization in services: implications from trade theory. In: Curtis J., Ciuriak D. (Eds.). Trade policy research 2002. Minister of Public Works and Government Services, Canada, 2002. 107-218.

[7] Dee P., Hanslow K, 2000, Multilateral liberalization of services trade. Productivity Commission Staff Research Paper, Ausinfo, Canberra.

[8] Findlay C., Warren T., 2000. Impediments to Trade in Services: Measurement and Policy Implications. Routledge: Sydney.

[9] Francois J., Hoekman B., 1999. Market access in the service sectors. Tinbergen Institute, mimeo.

[10] Francois J., Wooton, I, 2001. Market structure, trade liberalization, and the GATS. European Journal of Political Economy 17. 389-402.

[11] Head K., Mayer T., 2001. Everything you always wanted to know About CES (but were afraid to ask). Mimeo. 
[12] Hertel T., 1999. Potential gains from reducing trade barriers in manufacturing, services and agriculture. 24th Annual Economic Policy Conference, Federal Reserve Bank of St. Louis.

[13] Hoekman B., 1996. Assessing the General Agreement on Trade in Services. In Martin W., Winters A. (Eds). The Uruguay Round and the Developing Economies. Cambridge University Press: New York, D.C., 1996.

[14] Hoekman B., 2006. Trade in services, economic growth and development, and international cooperation: a survey of the literature. Mimeo.

[15] Hoffmann A., 2002. Imperfect competition in computable general equilibrium models — a primer. Economic Modelling 20. 119-139.

[16] Institut National De La Statistique, 1998. Les comptes de la nation, agregats et tableaux d'ensemble 1993-1997. INS Press: Tunis, 1998.

[17] Jensen J., Rutherford T., Tarr D., 2004. The impact of liberalizing barriers to foreign direct investment in services: the case of Russian accession to the world trade organization. World Bank Policy Research Working Paper 3391.

[18] Konan D., 2003. Alternative paths to prosperity: trade liberalization in Egypt and Tunisia. in Galal A., Hoekman B. (Eds). Arab economic integration: between hope and reality. Brookings Institution Press: Washington, D.C., 2003. 61-101.

[19] Konan D., Maskus K., 2000. Joint trade liberalization and tax reform in a small open economy: the case of Egypt. Journal of Development Economics 61. 365-392.

[20] Konan D., Maskus K., 2006. Quantifying the impact of services liberalization in a developing country. Journal of Development Economics. Forthcoming.

[21] Konan D., Van Assche A., 2005. V6 Documentation - Chapter 11.Q: Tunisia. GTAP Resource No. 1814.

[22] Low P., Mattoo A., 2000. Is there a better way? Alternative approaches to liberalization under GATS. In: Sauvé P., Stern R. (Eds). GATS 2000: new directions in services trade liberalization. Brookings Institution Press: Washington DC, 2000. 449-472. 
[23] Markusen J., Rutherford T., Tarr D., 2000. Foreign direct investment and the domestic market for expertise. World Bank Policy and Research Working Paper No. 2413.

[24] Markusen J., Rutherford T., Tarr D., 2005. Trade and direct investment in producer services and the domestic market for expertise. Canadian Journal of Economics 38. 758-777.

[25] Mattoo A., Sauvé P., 2003. Domestic Regulation and Services Trade Liberalization. Oxford University Press: Washington, D.C..

[26] Rutherford T., Rutstrom, E., Tarr D., 1995. The free trade agreement between Tunisia and the European Union. Mimeo.

[27] Varoudakis A., Rossotto C., 2004. Regulatory reform and performance in telecommunications: unrealized potential in the MENA countries. Telecommunications Policy 28. 59-78.

[28] Whalley J., 2004. Assessing the Benefits to developing countries of liberalization in services trade. World Economy 27. 1223-1253.

[29] Zarrouk J., 2000. Regulatory regimes and trade costs. In: Hoekman B., Zarrouk J. (Eds). Catching up with the competition: trade opportunities and challenges for Arab countries. University of Michigan Press: Ann Arbor, 2000. 


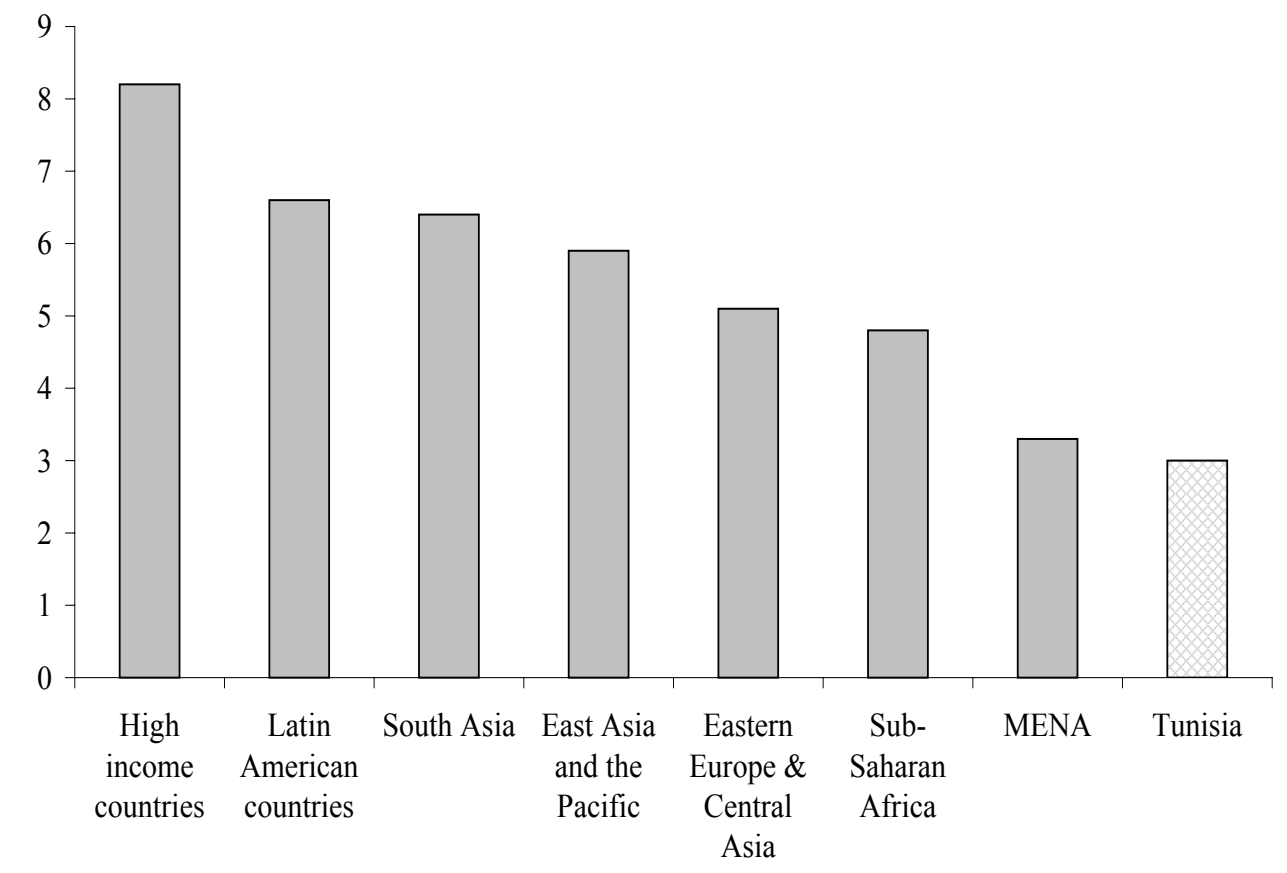

Source: Varoudakis and Rossotto (2004)

Figure 1: Telecommunications Liberalization Index (1999) 


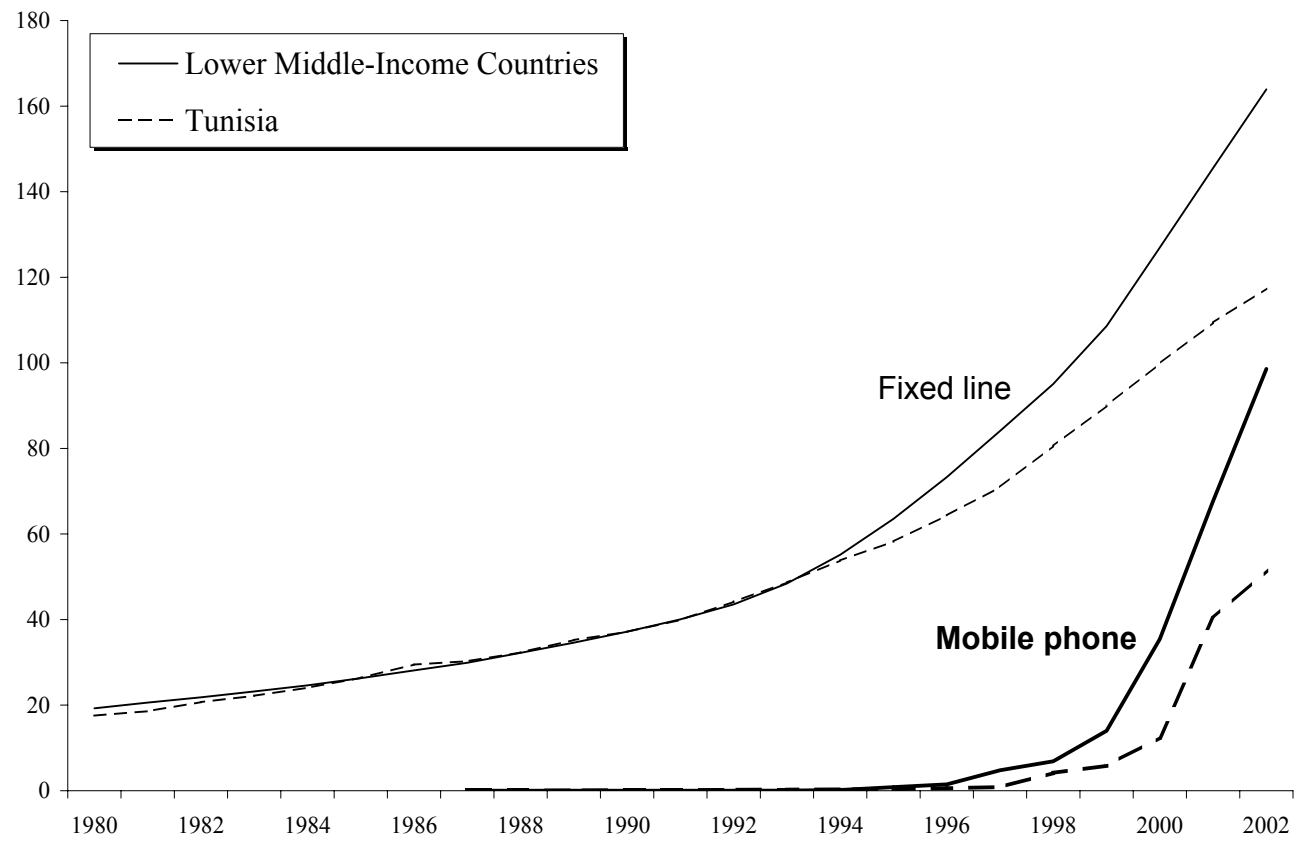

Source: International Telecommunications Union

Figure 2: Fixed Line and Mobile Phone Penetration Rates (per 1000 people) 


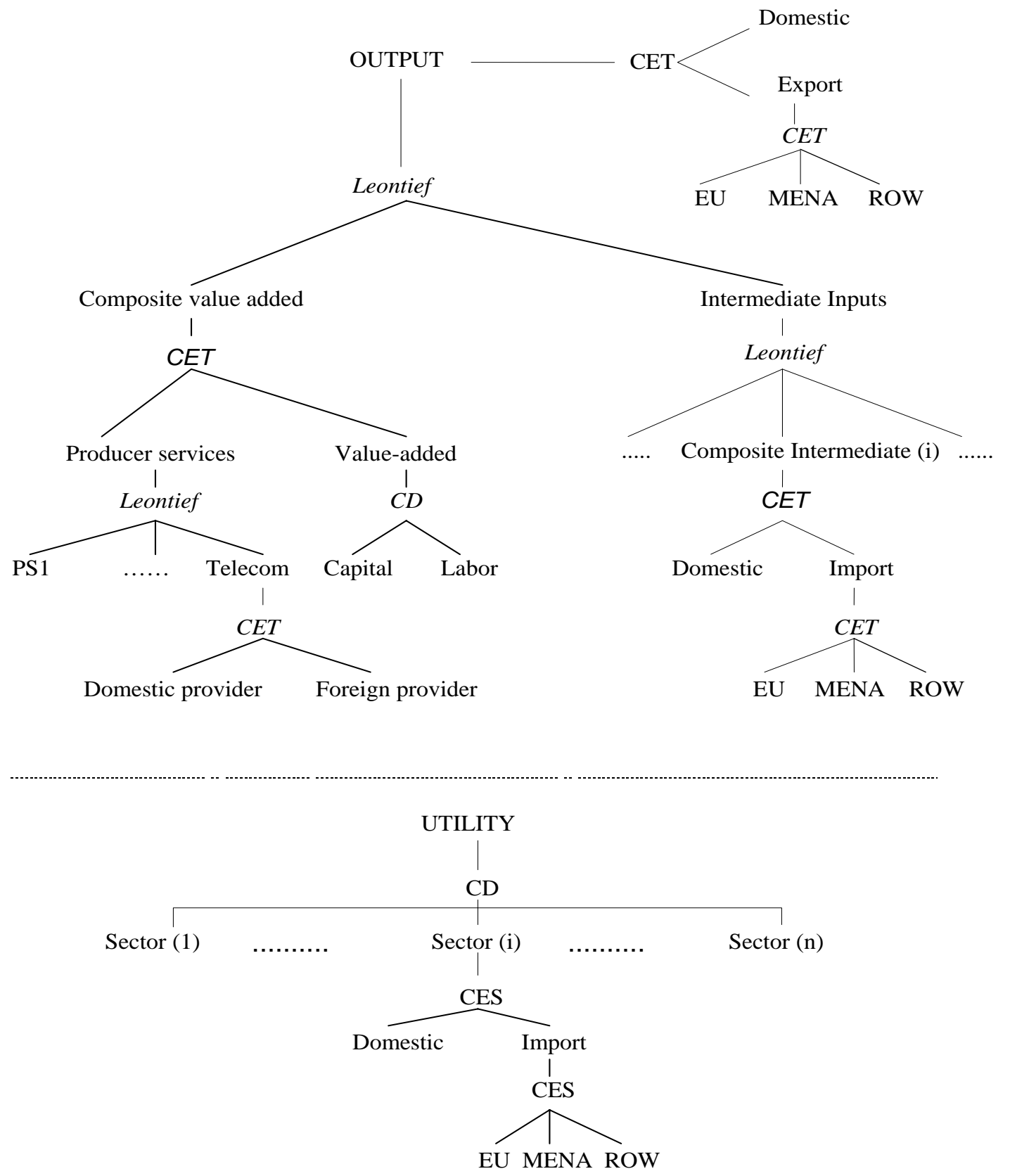

Figure 3: Nesting Structure of Tunisia CGE Model 
Table 1: Telecom Usage, Producer Service Usage, and Labor Intensity by Industry

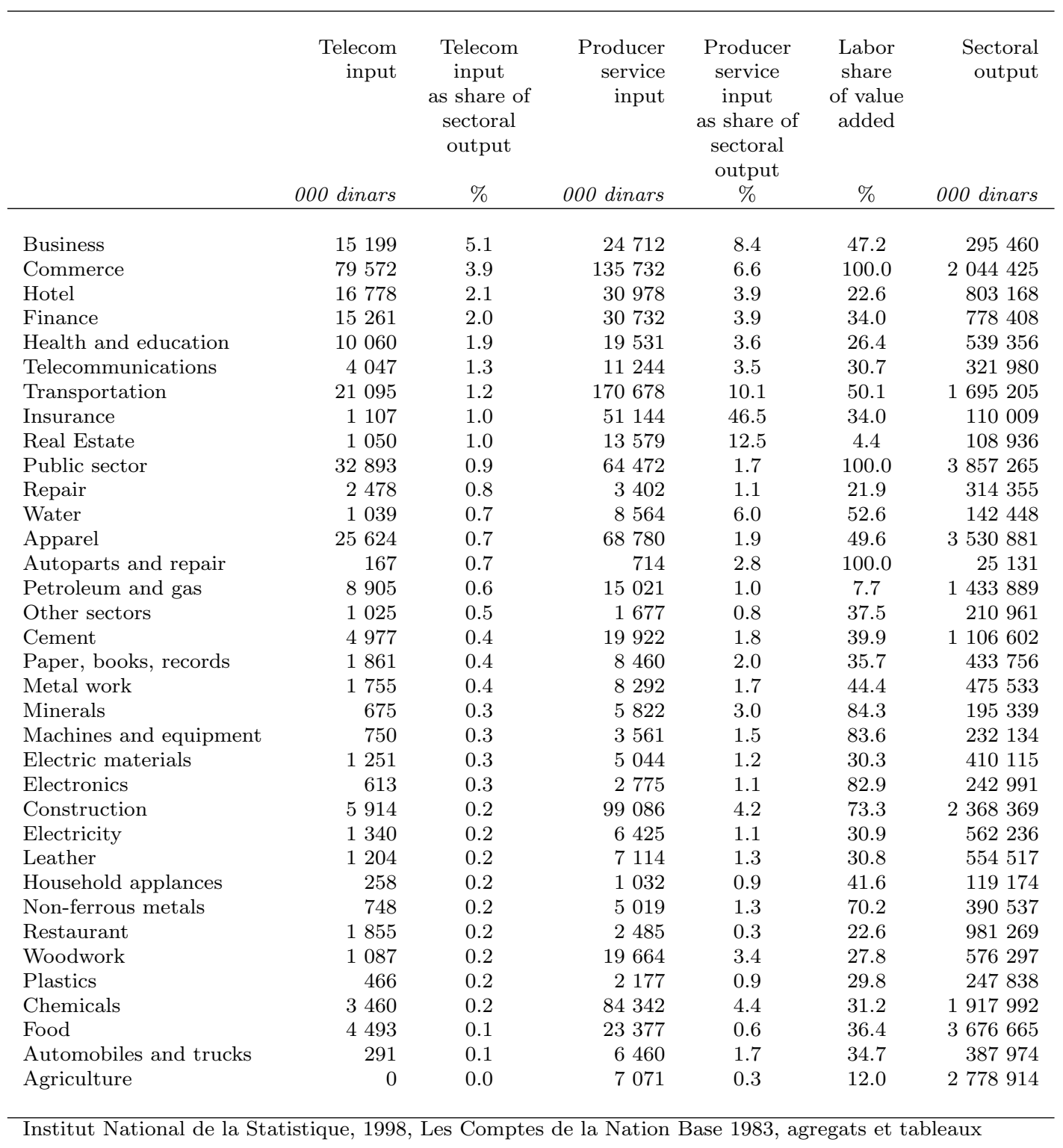


Table 2: Telecom Liberalization Scenarios

Foreign Entry with DUOPOLY Market Structure (\% change)

\begin{tabular}{lcccc}
\hline & \multicolumn{2}{c}{ symmetric costs } & \multicolumn{2}{c}{ asymmetric costs } \\
& $\begin{array}{l}\text { profit retention } \\
(1)\end{array}$ & $\begin{array}{c}\text { profit shifting } \\
\text { profit retention }\end{array}$ & $\begin{array}{c}\text { profit shifting } \\
(4)\end{array}$ \\
\hline & & & & \\
Telecom Sector Indicators & & & & \\
Telecom output & 18.31 & 18.31 & 53.06 & 53.06 \\
Composite telecom price & -0.07 & -0.07 & -0.15 & -0.15 \\
Macroeconomic Indicators & & & & \\
Household welfare (EV) & 0.19 & 0.02 & 0.65 & 0.26 \\
Output, real & 0.15 & 0.14 & 0.47 & 0.44 \\
Consumer price index & -0.19 & -0.16 & -0.59 & -0.55 \\
Aggregate exports & 2.49 & 2.49 & 6.99 & 6.99 \\
Aggregate imports & 0.89 & 0.89 & 2.29 & 2.29 \\
Return to capital & 0.10 & 0.10 & 0.29 & 0.29 \\
Return to labor & 0.37 & 0.37 & 0.80 & 0.80 \\
\hline
\end{tabular}

Foreign Entry with CARTEL Market Structure (\% change)

\begin{tabular}{lcccc}
\hline & \multicolumn{2}{c}{ symmetric costs } & \multicolumn{2}{c}{ asymmetric costs } \\
& $\begin{array}{c}\text { profit retention } \\
(5)\end{array}$ & $\begin{array}{c}\text { profit shifting } \\
\text { profit retention }\end{array}$ & $\begin{array}{c}\text { profit shifting } \\
(8)\end{array}$ \\
\hline Telecom Sector Indicators & & & & \\
Telecom output & 8.37 & & & \\
Composite telecom price & -0.04 & -0.37 & 8.47 & 8.47 \\
& & & -0.04 & -0.04 \\
Macroeconomic Indicators & & & & \\
Household welfare (EV) & 0.15 & -0.25 & 0.54 & -0.21 \\
Output, real & 0.11 & 0.08 & 0.36 & 0.31 \\
Consumer price index & -0.02 & -0.02 & -0.02 & -0.02 \\
Aggregate exports & 1.19 & 1.19 & 1.50 & 1.50 \\
Aggregate imports & 0.46 & 0.46 & 0.67 & 0.67 \\
Return to capital & 0.05 & 0.05 & 0.06 & 0.06 \\
Return to labor & 0.18 & 0.18 & 0.15 & 0.15 \\
\hline
\end{tabular}




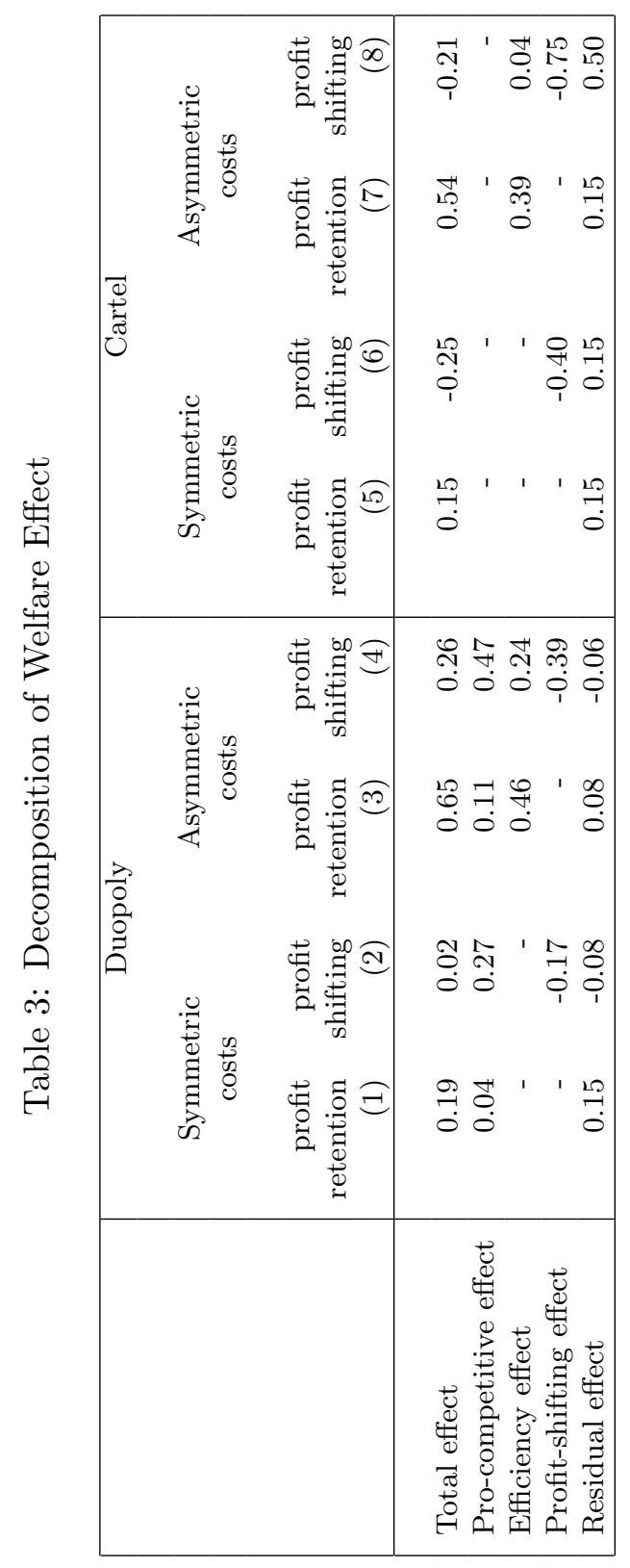


Table 4: Impact of Telecom Liberalization on Sectoral Output (\% change)

\begin{tabular}{|c|c|c|c|c|c|c|c|c|}
\hline & \multicolumn{4}{|c|}{ Duopoly } & \multicolumn{4}{|c|}{ Cartel } \\
\hline & \multicolumn{2}{|c|}{$\begin{array}{l}\text { Symmetric } \\
\text { costs }\end{array}$} & \multicolumn{2}{|c|}{$\begin{array}{c}\text { Asymmetric } \\
\text { costs }\end{array}$} & \multicolumn{2}{|c|}{$\begin{array}{l}\text { Symmetric } \\
\text { costs }\end{array}$} & \multicolumn{2}{|c|}{$\begin{array}{c}\text { Asymmetric } \\
\text { costs }\end{array}$} \\
\hline & $\begin{array}{r}\text { profit } \\
\text { retention } \\
(1)\end{array}$ & $\begin{array}{r}\text { profit } \\
\text { shifting } \\
(2)\end{array}$ & $\begin{array}{r}\text { profit } \\
\text { retention } \\
(3)\end{array}$ & $\begin{array}{r}\text { profit } \\
\text { shifting } \\
(4)\end{array}$ & $\begin{array}{r}\text { profit } \\
\text { retention } \\
(5)\end{array}$ & $\begin{array}{r}\text { profit } \\
\text { shifting } \\
(6)\end{array}$ & $\begin{array}{r}\text { profit } \\
\text { retention } \\
(7)\end{array}$ & $\begin{array}{r}\text { profit } \\
\text { shifting } \\
(8)\end{array}$ \\
\hline Business & 21.67 & 21.67 & 56.50 & 56.50 & 10.22 & 10.22 & 10.40 & 10.40 \\
\hline Commerce & -0.07 & -0.07 & -0.13 & -0.13 & 0.01 & 0.01 & 0.28 & 0.28 \\
\hline Hotel & -0.24 & -0.24 & -0.70 & -0.70 & -0.07 & -0.07 & 0.12 & 0.12 \\
\hline Finance & 3.13 & 3.13 & 7.82 & 7.82 & 1.54 & 1.54 & 1.79 & 1.79 \\
\hline Health and education & -0.47 & -0.47 & -1.36 & -1.36 & -0.14 & -0.14 & 0.22 & 0.22 \\
\hline Telecommunication & 18.31 & 18.31 & 53.06 & 53.06 & 8.37 & 8.37 & 8.47 & 8.47 \\
\hline Transportation & 9.01 & 9.01 & 22.87 & 22.87 & 4.32 & 4.32 & 4.55 & 4.55 \\
\hline Insurance & 11.67 & 11.67 & 29.95 & 29.95 & 5.55 & 5.55 & 5.76 & 5.76 \\
\hline Real estate & 4.82 & 4.82 & 11.52 & 11.52 & 2.72 & 2.72 & 4.79 & 4.79 \\
\hline Public sector & 0.19 & 0.19 & 0.36 & 0.36 & 0.10 & 0.10 & 0.09 & 0.09 \\
\hline Repair & 1.91 & 1.91 & 4.80 & 4.80 & 0.93 & 0.93 & 1.07 & 1.07 \\
\hline Water & 0.11 & 0.11 & 0.19 & 0.19 & 0.08 & 0.08 & 0.19 & 0.19 \\
\hline Apparel & 0.76 & 0.76 & 2.60 & 2.60 & 0.39 & 0.39 & 0.85 & 0.85 \\
\hline Autoparts and repair & 0.21 & 0.21 & 0.61 & 0.61 & 0.10 & 0.10 & 0.15 & 0.15 \\
\hline Petroleum and gas & 1.73 & 1.73 & 4.24 & 4.24 & 0.86 & 0.86 & 0.97 & 0.97 \\
\hline Other sectors & 0.38 & 0.38 & 0.95 & 0.95 & 0.23 & 0.23 & 0.51 & 0.51 \\
\hline Cement & 0.02 & 0.02 & 0.03 & 0.03 & 0.02 & 0.02 & 0.08 & 0.08 \\
\hline Paper, books, records & 0.26 & 0.26 & 0.64 & 0.64 & 0.16 & 0.16 & 0.37 & 0.37 \\
\hline Metal work & 0.08 & 0.08 & 0.15 & 0.15 & 0.07 & 0.07 & 0.23 & 0.23 \\
\hline Minerals & -0.29 & -0.29 & -0.73 & -0.73 & -0.09 & -0.09 & 0.17 & 0.17 \\
\hline Machines and equipment & 0.44 & 0.44 & 1.01 & 1.01 & 0.22 & 0.22 & 0.26 & 0.26 \\
\hline Electric materials & 0.58 & 0.58 & 1.17 & 1.17 & 0.30 & 0.30 & 0.30 & 0.30 \\
\hline Electronics & 0.47 & 0.47 & 1.13 & 1.13 & 0.21 & 0.21 & 0.10 & 0.10 \\
\hline Construction & 0.13 & 0.13 & 0.28 & 0.28 & 0.06 & 0.06 & 0.08 & 0.08 \\
\hline Electricity & 0.14 & 0.14 & 0.32 & 0.32 & 0.10 & 0.10 & 0.26 & 0.26 \\
\hline Leather & -0.50 & -0.50 & -1.42 & -1.42 & -0.17 & -0.17 & 0.15 & 0.15 \\
\hline Household appliances & -0.22 & -0.22 & -0.72 & -0.72 & -0.04 & -0.04 & 0.25 & 0.25 \\
\hline Non-ferrous metals & 0.03 & 0.03 & 0.08 & 0.08 & 0.03 & 0.03 & 0.12 & 0.12 \\
\hline Restaurant & -0.62 & -0.62 & -1.78 & -1.78 & -0.20 & -0.20 & 0.23 & 0.23 \\
\hline Woodwork & -0.19 & -0.19 & -0.56 & -0.56 & -0.04 & -0.04 & 0.16 & 0.16 \\
\hline Plastics & 0.25 & 0.25 & 0.59 & 0.59 & 0.16 & 0.16 & 0.39 & 0.39 \\
\hline Chemicals & -0.13 & -0.13 & -0.39 & -0.39 & -0.01 & -0.01 & 0.25 & 0.25 \\
\hline Food & -0.43 & -0.43 & -1.25 & -1.25 & -0.14 & -0.14 & 0.18 & 0.18 \\
\hline Automobiles and trucks & 0.11 & 0.11 & 0.16 & 0.16 & 0.09 & 0.09 & 0.28 & 0.28 \\
\hline Agriculture & -0.40 & -0.40 & -1.15 & -1.15 & -0.12 & -0.12 & 0.18 & 0.18 \\
\hline
\end{tabular}


Table 5: Senstivitiy Analysis - Impact of Profit Shifting on Total Welfare Effect

\begin{tabular}{|c|cc|cc|}
\hline $\begin{array}{c}\text { share of foreign } \\
\text { provider's profits } \\
\text { shifted abroad (\%) }\end{array}$ & symmetric costs & \multicolumn{2}{c}{ Cartel } \\
\hline 0 & 0.19 & 0.65 & 0.15 & 0.54 \\
10 & 0.17 & 0.60 & 0.11 & 0.47 \\
20 & 0.16 & 0.55 & 0.07 & 0.40 \\
30 & 0.14 & 0.50 & 0.03 & 0.32 \\
40 & 0.12 & 0.46 & -0.01 & 0.24 \\
50 & 0.11 & 0.42 & -0.05 & 0.17 \\
60 & 0.09 & 0.39 & -0.09 & 0.09 \\
70 & 0.07 & 0.35 & -0.13 & 0.02 \\
80 & 0.06 & 0.32 & -0.17 & -0.06 \\
90 & 0.04 & 0.30 & -0.21 & -0.13 \\
100 & 0.02 & 0.26 & -0.25 & -0.21 \\
\hline
\end{tabular}

Table 6: Sensitivity Analysis — Impact of Wedge Decomposition on Total Welfare Effect

\begin{tabular}{|c|c|c|c|c|c|c|c|c|}
\hline \multirow{3}{*}{$\begin{array}{c}\text { share of } \\
\text { cartel wedge } \\
\text { in total } \\
\text { price-cost } \\
\text { wedge }(\%)\end{array}$} & \multicolumn{4}{|c|}{ Duopoly } & \multicolumn{4}{|c|}{ Cartel } \\
\hline & symmet & ic costs & asymmet & ic costs & symmet & c costs & asymmet & ic costs \\
\hline & $\begin{array}{r}\text { profit } \\
\text { retention } \\
(1)\end{array}$ & $\begin{array}{r}\text { profit } \\
\text { shifting } \\
(2)\end{array}$ & $\begin{array}{r}\text { profit } \\
\text { retention } \\
(3)\end{array}$ & $\begin{array}{r}\text { profit } \\
\text { shifting } \\
(4)\end{array}$ & $\begin{array}{r}\text { profit } \\
\text { retention } \\
(5)\end{array}$ & $\begin{array}{r}\text { profit } \\
\text { shifting } \\
(6)\end{array}$ & $\begin{array}{r}\text { profit } \\
\text { retention } \\
(7)\end{array}$ & $\begin{array}{r}\text { profit } \\
\text { shifting } \\
(8)\end{array}$ \\
\hline 30 & 0.16 & 0.03 & 1.19 & 0.69 & 0.15 & -0.13 & 0.78 & -0.04 \\
\hline 40 & 0.17 & 0.03 & 0.84 & 0.41 & 0.15 & -0.22 & 0.67 & -0.14 \\
\hline 50 & 0.19 & 0.02 & 0.65 & 0.26 & 0.15 & -0.25 & 0.54 & -0.21 \\
\hline 60 & 0.21 & 0.02 & 0.52 & 0.16 & 0.15 & -0.24 & 0.40 & -0.22 \\
\hline 70 & 0.22 & 0.02 & 0.43 & 0.11 & 0.15 & -0.23 & 0.31 & -0.21 \\
\hline 80 & 0.24 & 0.02 & 0.36 & 0.07 & 0.15 & -0.21 & 0.24 & -0.21 \\
\hline 90 & 0.26 & 0.03 & 0.31 & 0.05 & 0.15 & -0.20 & 0.19 & -0.20 \\
\hline 100 & 0.28 & 0.03 & 0.28 & 0.03 & 0.15 & -0.19 & 0.15 & -0.19 \\
\hline
\end{tabular}

